\title{
Time-resolved gas-phase kinetic, quantum chemical, and RRKM studies of reactions of silylene with alcohols
}

Article

Accepted Version

Becerra, R., Cannady, J. P. and Walsh, R. (2011) Timeresolved gas-phase kinetic, quantum chemical, and RRKM studies of reactions of silylene with alcohols. Journal of Physical Chemistry A, 115 (17). pp. 4231-4240. ISSN 10895639 doi: https://doi.org/10.1021/jp111750v Available at https://centaur.reading.ac.uk/32062/

It is advisable to refer to the publisher's version if you intend to cite from the work. See Guidance on citing.

To link to this article DOI: http://dx.doi.org/10.1021/jp111750v

Publisher: American Chemical Society

All outputs in CentAUR are protected by Intellectual Property Rights law, including copyright law. Copyright and IPR is retained by the creators or other copyright holders. Terms and conditions for use of this material are defined in the End User Agreement.

www.reading.ac.uk/centaur 
Central Archive at the University of Reading

Reading's research outputs online 


\section{Time-resolved gas-phase kinetic, quantum chemical and RRKM}

\section{studies of reactions of silylene with alcohols}

Rosa Becerra*

Instituto de Quimica-Fisica 'Rocasolano', C.S.I.C., C/ Serrano 119, 28006 Madrid, Spain

J. Pat Cannady

Dow Corning Corporation, P.O. Box 994, Mail CO1232, Midland, Michigan, 48686-0994

Robin Walsh*

Department of Chemistry, University of Reading, Whiteknights, P.O. Box 224, Reading, RG6 $6 A D, U K$

\section{Abstract:}

Time-resolved kinetic studies of silylene, $\mathrm{SiH}_{2}$, generated by laser flash photolysis of 1silacyclopent-3-ene and phenylsilane, have been carried out to obtain rate constants for its bimolecular reactions with methanol, ethanol, 1-propanol, 1-butanol and 2-methyl-1-butanol. The reactions were studied in the gas phase over the pressure range 1-100 Torr in $\mathrm{SF}_{6}$ bath gas, at room temperature. In the study with methanol several buffer gases were used. All five reactions showed pressure dependences characteristic of third body assisted association reactions. The rate constant pressure dependences were modelled using RRKM theory, based on $E_{\mathrm{o}}$ values of the association complexes obtained by ab initio calculation (G3 level). Transition state models were adjusted to fit experimental fall-off curves and extrapolated to obtain $k^{\infty}$ values in the range 1.9 to $4.5 \times 10^{-10} \mathrm{~cm}^{3}$ molecule $\mathrm{s}^{-1}$. These numbers, corresponding to the true bimolecular rate constants, indicate efficiencies of between 16 and $67 \%$ of the collision rates for these reactions. In the reaction of $\mathrm{SiH}_{2}+\mathrm{MeOH}$ there is a small kinetic component to the rate which is second order in $\mathrm{MeOH}$ (at low total pressures). This suggests an additional catalysed 
reaction pathway, which is supported by the ab initio calculations. These calculations have been used to define specific $\mathrm{MeOH}-$ for- $\mathrm{H}_{2} \mathrm{O}$ substitution effects on this catalytic pathway. Where possible our experimental and theoretical results are compared with those of previous studies.

\section{Introduction}

Silylene chemistry has been of interest for many years ${ }^{1}$. Silylenes are important reactive intermediates in the photochemical and thermal reactions of organosilicon compounds. Their chemistry has practical significance in industrial applications involving chemical vapour deposition (CVD) leading to formation of electronic device materials. Timeresolved kinetic studies of the simplest silylene, $\mathrm{SiH}_{2}$, have shown it reacts rapidly with many chemical species at close to collision rates. ${ }^{2-4}$ This can be readily understood in terms of its structure. Silylene is a ground state singlet species $\left({ }^{1} \mathrm{~A}_{1}\right)$ with an electron pair in a hybrid orbital and a vacant orbital of $\pi$ symmetry. This empty orbital means that $\mathrm{SiH}_{2}$ is highly electrophilic and electron donors will readily coordinate to silicon through the vacant orbital to form a silylene-base complex. If the electron donor (Lewis base) is an alcohol, this complex is zwitterionic in nature. Complexes of silylenes with alcohols have been directly observed in low temperature matrices ${ }^{5}$ and in solution ${ }^{6-8} \cdot \mathrm{SiH}_{2}$-complexes can, in principle, react further by $\mathrm{H}$-transfer from oxygen to the $\mathrm{Si}$ atom ${ }^{1,3-4,9}$

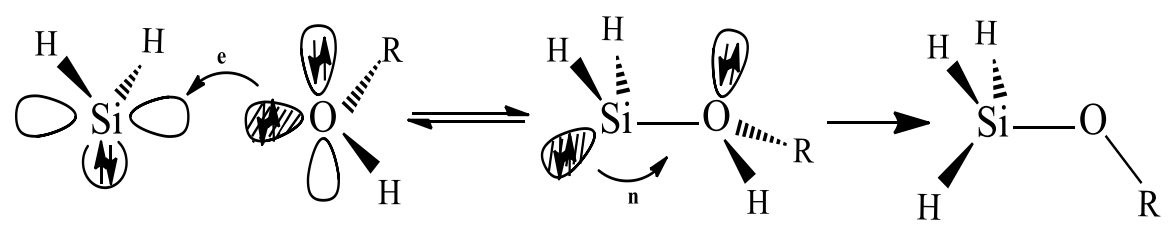

Theoretical calculations indicate ${ }^{10-15}$, however, that this second step, the unimolecular conversion of the complex to a siloxane, has a substantial energy barrier and is therefore likely to be slow. Kinetic studies both in the gas phase ${ }^{4,14-18}$ and in solution ${ }^{6-8,19-20}$ support the formation of these complexes but no evidence has been found for their unimolecular 
isomerisation. As to whether a second step in this mechanism can actually occur, the evidence points to a catalysed conversion of the complex to product. This has been found for the prototype reaction of $\mathrm{SiH}_{2}+\mathrm{H}_{2} \mathrm{O}$ in the gas-phase ${ }^{15}$ as well as for the reactions of $\mathrm{SiMe}_{2}$ and $\mathrm{SiPh}_{2}$ with $\mathrm{MeOH}$ in solution ${ }^{8}$, where the reactions of the complexes with $\mathrm{MeOH}$ have been found to occur at close to diffusion controlled rates. The catalysed process for the $\mathrm{SiH}_{2}+\mathrm{H}_{2} \mathrm{O}$ reaction is further supported by theoretical calculations ${ }^{15}$.

In order to probe this reaction further, and as part of our investigation of the gas-phase reactions of $\mathrm{SiH}_{2}$, we turn our attention to its reaction with several alcohols, viz. methanol, ethanol, 1-propanol, 1-butanol and 2-dimethyl-1-butanol. The reaction of $\mathrm{SiH}_{2}$ with methanol has already been studied theoretically ${ }^{12-13}$ and experimentally ${ }^{14}$. Alexander, King and Lawrance $(\mathrm{AKL})^{14}$ found the gas-phase reaction to be a pressure dependent, third body assisted association process, consistent with the reversible formation of the zwitterionic complex. Our kinetic studies of $\mathrm{SiH}_{2}$ with $\mathrm{H}_{2} \mathrm{O}^{15,18}$ and $\mathrm{Me}_{2} \mathrm{O}^{21}$ are also consistent with the formation of a complex. In the gas-phase the reaction stops at this stage within the experimental time frame (ca $10^{-6} \mathrm{~s}$ ) and the catalysed process is only observed (for $\mathrm{SiH}_{2}+$ $\mathrm{H}_{2} \mathrm{O}$ ) at low pressures when equilibrium with the complex is established slowly. One of the difficulties of the gas phase studies is that the true bimolecular rate constant (for the formation of the zwitterion), ie the pressure-independent value, can only be obtained by extrapolation. Since association processes of reactive molecules of any class tend to become less pressure dependent as the molecular size and complexity of the substrate species increases, we reasoned that kinetic studies of $\mathrm{SiH}_{2}$ with larger alcohols should get closer to the high pressure limit of this important prototype reaction of silylene with O-donor molecules. As a secondary question we were also interested as to whether any evidence for the catalysed isomerisation of the $\mathrm{H}_{2} \mathrm{Si} \cdot \cdot \mathrm{O}(\mathrm{H}) \mathrm{Me}$ complex could be obtained. 
We therefore decided to reinvestigate the reaction of $\mathrm{SiH}_{2}$ with methanol at room temperature using several buffer gases, and in addition, to extend this investigation to the higher alcohols. Our study includes both kinetic measurements, RRKM modelling and quantum chemical calculations in order to obtain as full a picture of the process as possible.

\section{Experimental Section}

Equipment, Chemicals and Method. $\mathrm{SiH}_{2}$ was produced by the $193 \mathrm{~nm}$ flash photolysis of phenylsilane $\left(\mathrm{PhSiH}_{3}\right)$ or 1-silacyclopent-3-ene (SCP) using a Coherent Compex 100 exciplex laser. Photolysis pulses (ca $4 \mathrm{~cm} \times 1 \mathrm{~cm}$ cross-section) were fired into a variable temperature quartz reaction vessel with demountable windows, at right angles to its main axis. $\mathrm{SiH}_{2}$ concentrations were monitored in real time by means of a Coherent 699-21 single-mode dye laser pumped by an Innova 90-5 argon ion laser and operating with Rhodamine 6G. The monitoring laser beam was multipassed between 32 and 40 times along the vessel axis, through the reaction zone, to give an effective path length of up to $1.6 \mathrm{~m}$. A portion of the monitoring beam was split off before entering the vessel for reference purposes. The laser wavelength was set by reference to a known coincident transition in the visible spectrum of $I_{2}$ vapour and was checked at frequent intervals during the experiments. The monitoring laser was tuned to $17259.50 \mathrm{~cm}^{-1}$, corresponding to a known strong ${ }^{\mathrm{R}} \mathrm{Q}_{\mathrm{O}, \mathrm{J}}(5)$ vibration-rotation transition ${ }^{22}$ in the

$\mathrm{SiH}_{2}$ absorption band. Light signals $\tilde{A}^{1} \mathrm{~B}_{1}(0,2,0) \leftarrow \tilde{X}^{1} \mathrm{~A}_{1}(0,0,0)$ were measured by a dual photodiode/differential amplifier combination and signal decays were stored in a transient recorder (Datalab DL910) interfaced to a BBC microcomputer. This was used to average the decays of between 5 and 20 photolysis laser shots (at a repetition rate of 0.5 or $1 \mathrm{~Hz}$ ). The averaged decay traces were processed by fitting the data to an exponential form using a nonlinear least squares package. This analysis provided the values for first-order rate coefficients, 
$k_{\text {obs }}$, for removal of $\mathrm{SiH}_{2}$ in the presence of known partial pressures of substrate gas. Static gas mixtures were used and the optics were cleaned regularly.

Gas mixtures for photolysis were made up, containing between 2.5 and 2.8 mTorr of SCP or 2.5 and 3.6 mTorr of $\mathrm{PhSiH}_{3}$, a few mTorr of $\mathrm{ROH}$ (see following) and inert diluent $\left(\mathrm{SF}_{6}\right)$ at added pressures of between 0 and 100 Torr. For each series of experiments the pressures of ROH were: 0-2 Torr of $\mathrm{CH}_{3} \mathrm{OH}(\mathrm{MeOH}), 0-230$ mTorr of $\mathrm{C}_{2} \mathrm{H}_{5} \mathrm{OH}(\mathrm{EtOH}), 0-100$ mTorr $1-\mathrm{C}_{3} \mathrm{H}_{7} \mathrm{OH}$ (1-PrOH), 0-80 mTorr of 1- $\mathrm{C}_{4} \mathrm{H}_{9} \mathrm{OH}$ (1-BuOH), 0-53 mTorr of $\mathrm{C}_{5} \mathrm{H}_{11} \mathrm{OH}$ (2-MBA). Other buffer gases $\left(\mathrm{N}_{2}\right.$, Ar and $\left.\mathrm{C}_{3} \mathrm{H}_{8}\right)$ were used for the experiments with $\mathrm{MeOH}$. Pressures of $\mathrm{N}_{2}$ varied from 5 to 200 Torr; of Ar from 10 to 100 Torr and of $\mathrm{C}_{3} \mathrm{H}_{8}$ from 5 to 40 Torr. Pressures were measured by capacitance manometers (MKS, Baratron).

All gases used in this work were frozen at $77 \mathrm{~K}$ and pumped free of any vestiges of air prior to use. $\mathrm{PhSiH}_{3}$ (99.9\%) was obtained from Ventron-Alfa (Petrarch). SCP was prepared by the reduction of 1,1-dichloro-1-silacyclopent-3-ene with $\mathrm{LiAlH}_{4}$ in ether in $60 \%$ yield following literature procedures ${ }^{23}$. SCP was purified by low pressure distillation to greater than $90 \%$. MeOH was from Fisher Scientific (99.9\%), EtOH was from BDH (Analar, 99.7-100\%), 1-PrOH was from Fisher Scientific (99.8\%), 1-BuOH from Acros Organics, (99.4\%) and 2MBA from Acros Organics (99\%). Sulfur hexafluoride, $\mathrm{SF}_{6}$, (no GC-detectable impurities) was from Cambrian Gases.

Ab Initio Calculations. The electronic structure calculations were performed initially with the Gaussian 98 and subsequently the Gaussian 03 software packages ${ }^{24}$. All structures were determined by energy minimization at the MP2=Full/6-31G (d) level. Stable structures, corresponding to energy minima, were identified by possessing no negative eigenvalues of the Hessian matrix. The standard Gaussian-3 (G3) compound method ${ }^{25}$ was employed to determine final energies for all local minima. For transition states the elements of the G3 method were used, viz: optimization to TS at HF/6-31G(d), frequencies at $\mathrm{HF} / 6-31 \mathrm{G}(\mathrm{d})$, optimization to TS at 
MP2=full/6-31G(d), followed by four single point energy determinations at the MP2=full/631G(d) geometry, viz: QCISD(T)/6-31G(d), MP4/6-31+G(d), MP4/6-31G(2df,p), and MP2= full/G3large, and the values were combined according to the G3 procedure. ${ }^{25}$ The identities of the transition state structures were verified by calculation of Intrinsic Reaction Co-ordinates ${ }^{26}$ (IRC) at the MP2=Full/6-31G(d) or B3LYP/6-31G(d) levels. Reaction barriers were calculated as differences in G3 enthalpies at $298.15 \mathrm{~K}$. Some free energies values were also obtained.

\section{Results}

Kinetics. For each reaction of interest it was independently verified during preliminary experiments that, in a given reaction mixture, $k_{\mathrm{obs}}$ values were not dependent on the exciplex laser energy or number of photolysis shots. Because static gas mixtures were used, tests with up to 20 shots were carried out. The constancy of $k_{\mathrm{obs}}$ (5 shot averages) showed no effective depletion of reactants in any of the systems. For each system the precursor pressures were kept fixed to ensure a constant (but always small) contribution $\left(k_{\text {int }}\right)$ to $k_{\text {obs }}$ values. In order to test the nature of the kinetics a series of experiments was carried out with different partial pressures of each alcohol. All experiments were carried out at room temperature (297 K).

\section{$\underline{\mathrm{SiH}_{2}} \underline{+\mathrm{MeOH}}$}

For the reaction with methanol the system was studied in three different ways. First (a) with no added buffer gas, then (b) with added $\mathrm{SF}_{6}$ as buffer gas to a total pressure of 5 Torr, and finally (c) with $\mathrm{SF}_{6}$ added at a fixed partial pressure of 2 Torr (but variable total pressure). The results of these experiments can be seen in Figure 1. Plots (a) and (c) are curved and show that the dependence of $k_{\mathrm{obs}}$ is not simply linear in $[\mathrm{MeOH}]$. The data were fitted to the equation:

$$
k_{\mathrm{obs}}=k_{\mathrm{int}}+k_{1} \mathrm{x}+k_{2} \mathrm{x}^{2}
$$


Using LSQ fitting procedures rate constant values were obtained for each plot. These are shown in Table 1. The error limits are single standard deviations.

As we can see in Figure 1 this reaction system shows a significant total pressure dependence. This was investigated further using several buffer gases: $\mathrm{Ar}, \mathrm{N}_{2}, \mathrm{C}_{3} \mathrm{H}_{8}$ and $\mathrm{SF}_{6}$. These experiments were done keeping the amount of $\mathrm{MeOH}$ fixed at $250 \mathrm{mTorr}$ and varying the total amount of buffer gas. The second order rate constant was calculated using: $k$ (secondorder $)=\left(k_{\mathrm{obs}}-k_{\mathrm{int}}\right) /[\mathrm{MeOH}]$ at each of a set of total pressures up to 100 Torr. This is justified on the assumption that clean second order behaviour is shown at total pressures above 5 Torr, as indicated in Figure 1(b). The results are shown in Figure 2 in a log-log plot for convenience. It can be seen from the relative positions of the plots that Ar is the least efficient collider, followed by $\mathrm{N}_{2}$ with $\mathrm{C}_{3} \mathrm{H}_{8}$ and $\mathrm{SF}_{6}$ practically the same. Collision efficiencies were calculated by using RRKM modelling (see next section).

\section{$\underline{\mathrm{SiH}_{2}} \underline{+}$ other alcohols}

For the remaining systems, viz $\mathrm{SiH}_{2}$ with $\mathrm{EtOH}, 1-\mathrm{PrOH}, 1-\mathrm{BuOH}$ and 2-MBA experiments were done using different partial pressures of the alcohol but keeping the total pressure fixed at 10 Torr by addition of buffer gas $\left(\mathrm{SF}_{6}\right)$. Second order rate plots are shown in Figures 3 and 4 and we can see here that reasonably linear plots resulted. The second-order rate constants obtained by least-squares fitting are collected in Table 2 . The error limits quoted are single standard deviations. It can be clearly seen that at 10 Torr total pressure the rate constants increase as the size of alcohol increases.

Just as with the $\mathrm{MeOH}$, the pressure dependence of these reactions was also investigated, by carrying out experiments with small, but fixed, amounts of each alcohol and varying the total pressure using $\mathrm{SF}_{6}$ as buffer gas. Second order kinetics was assumed. Figure 5 shows the pressure dependences of the rate constants for reactions of $\mathrm{SiH}_{2}$ with the rest of 
the alcohols studied in this work. As for $\mathrm{SiH}_{2}$ with $\mathrm{MeOH}$, the pressure dependences of the second order rate constants were fitted with RRKM models (see next section).

Ab initio calculations. Using the G3 method we examined first the energy surface for the $\mathrm{CSiH}_{6} \mathrm{O}$ species $\left(\mathrm{SiH}_{2}+\mathrm{MeOH}\right.$ reaction). As expected, we found three stable species (or combination of species), viz (i) $\mathrm{H}_{2} \mathrm{Si} \cdots \mathrm{OHMe}$, the initial complex of $\mathrm{SiH}_{2}+\mathrm{MeOH}$, (ii) $\mathrm{SiH}_{3} \mathrm{OMe}$ (methoxysilane), the lowest energy species on the surface, and (iii) $\mathrm{H}_{2}+\mathrm{HSiOMe}$ (methoxysilylene in both cis (c) and trans (t) forms). In addition we have located five transition states, TS1 leading from $\mathrm{H}_{2} \mathrm{Si} \cdots \mathrm{OHMe}$ to $\mathrm{SiH}_{3} \mathrm{OMe}$, TS2c/TS2t leading from $\mathrm{H}_{2} \mathrm{Si} \cdots \mathrm{OHMe}$ to $\mathrm{H}_{2}+\mathrm{HSiOMe}\left(\mathrm{c}\right.$ and $\mathrm{t}$ ) via $\mathrm{H}_{2}$ elimination and TS3c/TS3t connecting $\mathrm{SiH}_{3} \mathrm{OMe}$ to $\mathrm{H}_{2}+\mathrm{HSiOMe}$ (c and $\mathrm{t}$ ). The transition states for $\mathrm{H}_{2}$ elimination from $\mathrm{H}_{2} \mathrm{Si} \ldots \mathrm{OHMe}$ and from $\mathrm{SiH}_{3} \mathrm{OMe}$ are clearly different from one another. The structures of all species are shown in Figure 6 and their enthalpy values are listed in Table 3 as well as being represented on the potential energy (enthalpy) surface in Figure 7.

We then turned our attention to the $\mathrm{C}_{2} \mathrm{SiH}_{10} \mathrm{O}_{2}$ species $\left(\mathrm{SiH}_{2}+2 \mathrm{MeOH}\right.$ reaction). Initially this was a more limited search designed to investigate the possible catalysed $\mathrm{O}-\mathrm{H}$ insertion pathway of $\mathrm{SiH}_{2}$ with methanol. Two new stable species were found, viz (i) $\mathrm{H}_{2} \mathrm{Si} \cdots(\mathrm{OHMe})_{2}$, a complex of $\mathrm{SiH}_{2}$ with two molecules of methanol (which can also be regarded as an $\mathrm{H}$-bonded complex of the second $\mathrm{MeOH}$ molecule with the initial $\mathrm{H}_{2} \mathrm{Si} \cdots \mathrm{OHMe}$ complex) and (ii) $\mathrm{SiH}_{3} \mathrm{O}(\mathrm{Me}) \cdots \mathrm{OHMe}$, another H-bonded complex, in this case between methoxysilane and an $\mathrm{MeOH}$ molecule. The latter is the lowest energy species of these two and is essentially the reaction product. There is one transition state, TS4a, between (i) and (ii). It is worth noting that whereas TS1 (for $\mathrm{SiH}_{2}+\mathrm{MeOH}$ ) lies above the reactants, TS4a (for $\mathrm{SiH}_{2}+2 \mathrm{MeOH}$ ) lies well below the reactants in energy. The structures of these species are also shown in Figure 6 and enthalpies listed in Table 4. Because this exercise only allowed us to make an overall comparison of the catalytic effects of $\mathrm{MeOH}$ and $\mathrm{H}_{2} \mathrm{O}^{15}$, we 
extended it to include the specific effects of $\mathrm{MeOH}$ and $\mathrm{H}_{2} \mathrm{O}$ on the two zwitterions, $\mathrm{H}_{2} \mathrm{Si} \cdot \cdot \mathrm{OH}_{2}$ and $\mathrm{H}_{2} \mathrm{Si} \cdot \cdot \mathrm{O}(\mathrm{H}) \mathrm{Me}$ in order to try to gain greater insight. A summary of these results is also shown in Table 4 and further details are given in the supporting information.

As a final exercise we calculated the energies for forming the complexes between $\mathrm{SiH}_{2}$ and the other alcohols which were studied experimentally in this work. These are shown in Table 5. The G3 procedure worked fine for all the reactions except that for $\mathrm{SiH}_{2}$ with 2-MBA for which the molecular size was too large for the calculation. This system was calculated at the B3LYP/6-311+G(2d,p)//B3LYP/6-31G(d) level and then adjusted empirically by the amount $\left(-15 \mathrm{~kJ} \mathrm{~mol}^{-1}\right)$ by which this level of calculation differed from G3 for the other four alcohols.

RRKM calculations. The pressure dependence of an association reaction corresponds exactly to that of the reverse unimolecular dissociation process providing there are no other perturbing reaction channels. Although the detailed ab initio calculations for $\mathrm{SiH}_{2}$ $+\mathrm{MeOH}$ suggest the possibility of other channels there is no evidence from the kinetics (see discussion) of any such channel occurring under experimental conditions, and so we have carried out RRKM calculations ${ }^{27}$ on the unimolecular dissociation processes of all the zwitterionic donor-acceptor complexes, $\mathrm{H}_{2} \mathrm{Si} \cdots \mathrm{OHR}$, viz:

$$
\mathrm{H}_{2} \mathrm{Si} \cdots \mathrm{OHR} \rightarrow \mathrm{H}_{2} \mathrm{Si}+\mathrm{ROH}
$$

where $\mathrm{R}=\mathrm{Me}-$, Et-, 1-Pr-, 1-Bu- and EtCHMeCH${ }_{2}-$.

Since none of these complexes has been isolated, let alone studied experimentally, we are forced to make estimates of the necessary parameters for these calculations. This has been done as follows. First the likely Arrhenius $A$ factors for these decomposition reactions were estimated. On the assumption of similar values for $\Delta S^{\mathrm{o}}(1,-1)$ and $\log A_{1}$ to those for $\mathrm{SiH}_{2}+\mathrm{H}_{2} \mathrm{O}^{18}$ and $\mathrm{SiH}_{2}$ + cyclic ethers ${ }^{28}$, values in the range $10^{15}$ to $10^{17} \mathrm{~s}^{-1}$ were initially investigated. These were now used to assign the vibrational wavenumbers for the transition state by adjustment of the key 
transitional mode values of the zwitterionic species, using the standard Transistion State Theory formula, $A=(e k T / h) \exp \left(\Delta S^{\ddagger} / R\right)$. Since the wavenumbers for the reacting molecules (the zwitterions) were also not known they were estimated by use the known assignments for $\mathrm{SiH}_{2}{ }^{29}$ and $\mathrm{MeOH}^{30}$ and the use of group values ${ }^{31}$. Whether precise values of all vibrational wavenumbers are correct or not is not important provided the entropies of activation, i.e. values of $\Delta S^{\ddagger}$, are matched. This applies also to models in which low wavenumber vibrations are replaced by internal rotations in the transition $\operatorname{state}^{27}$. An example of the assignment of both molecule and transition state, for decomposition of $\mathrm{H}_{2} \mathrm{Si} \cdots \mathrm{OHMe}$, is shown in Table 6 which also includes the Lennard-Jones collision number value. The assignments for other choices of $A$ factor and for the decompositions of the other zwitterionic species are shown in the supporting information. The values for the critical energies, $E_{0}$, employed in these calculations were those given by the ab initio calculations (Table 5). We have used a weak collisional (stepladder) model for collisional deactivation, because there is overwhelming evidence against the strong collision assumption ${ }^{32}$. The average energy removal parameter, $\langle\Delta E\rangle_{\text {down }}$ was taken as $12.0 \mathrm{~kJ} \mathrm{~mol}^{-1}\left(1000 \mathrm{~cm}^{-1}\right)$ when $\mathrm{SF}_{6}$ was used as buffer gas (for all alcohols). For the other collider gases, used in the $\mathrm{SiH}_{2}+\mathrm{MeOH}$ studies, the values for $\langle\Delta E\rangle_{\text {down }}$ and $Z_{\mathrm{LJ}}$ are shown in Table 7.

The least well known feature of these calculations is the nature (tight or loose) of the transition states of these reactions. These determine both the positions of the "fall-off" curves and their curvatures. Thus optimising the fit to the experimental curves may be used to refine the transition state (characterised by its decomposition $A$ factor) and also to pinpoint the value of $k^{\infty}$, the high pressure limiting rate constant. This is illustrated for the $\mathrm{SiH}_{2}+\mathrm{MeOH}$ reaction in Figure 8. This shows the fits of the transition state models corresponding to values of 15 and 16 for $\log \left(A / \mathrm{s}^{-1}\right)$. It can be seen that, although both models fit tolerably well, the latter provides the better fit. Using this model the pressure dependence data for the other buffer gases were fitted by 
varying the collisional deactivation model step size. The fits are shown in Figures 9 and 10 . Because one of the important modes of the decomposing molecule may be regarded as an internal rotation, we have further tested a model in which the lowest wavenumber vibration (the $\mathrm{Si} \cdots \mathrm{O}$ torsion) has been replaced by an internal rotation (in both molecule and transition state). This has been fitted to the looser transition state $\left(A=10^{16} \mathrm{~s}^{-1}\right)$. The resulting fall-off curve is almost identical to that from the harmonic vibration only model, thus showing that this change makes little difference.

When the same exercise was carried out for the reactions of $\mathrm{SiH}_{2}$ with the other alcohols, it was found necessary to extend the RRKM modelling to even looser transition states, up to those corresponding to $\log \left(A / \mathrm{s}^{-1}\right)=17$. The plots of best fit fall-off curves are shown in Figure 5 . The summaries of the vibrational assignments for these models are given in the supporting information. The values of $k^{\infty}$ and the collisional efficiencies resulting from the fits, are given in Table 8. Again it was found that the substitution of an internal rotation for harmonic vibration in the molecular and transition state models made almost no difference to the fits. Other details, such as the Lennard Jones collision parameters, are also given in the supporting information.

As a separate exercise and in order to verify that the unimolecular conversion of the $\mathrm{H}_{2} \mathrm{Si}$..OHMe complex is not competitive under the conditions of these experiments, we constructed transition states for reaction via TS1 and TS2t. Details are given in the supporting information. Calculations were carried out at $297 \mathrm{~K}$ and the results are given in Table 9.

\section{Discussion}

General Comments and Rate Constant Comparisons. The main experimental purpose of this study was to measure the rate constants and their pressure dependences for the reactions of $\mathrm{SiH}_{2}$ with alcohols. This has been accomplished. The only previous experimental information (in the gas phase) is for $\mathrm{SiH}_{2}+\mathrm{MeOH}^{14}$. Alexander, King and Lawrance (AKL) ${ }^{14}$ 
measured the rate constants at $294 \mathrm{~K}$ for $\mathrm{SiH}_{2}+\mathrm{MeOH}$ in $\mathrm{Ar}$ at total pressures of between 100 and 800 Torr. The only overlap with this work occurs at 100 Torr. The value found by AKL is $1.60 \times 10^{-11} \mathrm{~cm}^{3}$ molecule ${ }^{-1} \mathrm{~s}^{-1}$ in reasonable agreement with our value of $1.80 \times 10^{-11} \mathrm{~cm}^{3}$ molecule $\mathrm{s}^{-1}$. A comparison of the experimental pressure dependence of the reaction in $\mathrm{Ar}$ observed by AKL with that from the RRKM modelling is, however, also possible (see below). There is no previous kinetic information for the reactions of $\mathrm{SiH}_{2}$ with $\mathrm{EtOH}, 1-\mathrm{PrOH}, 1-$ $\mathrm{BuOH}$ and 2-MBA with which to compare these results.

The present study of the reaction between $\mathrm{SiH}_{2}$ and $\mathrm{MeOH}$ indicates a greater kinetic complexity than found hitherto. At pressures below 5 Torr, with or without added inert gas, the second order plots (Figure 1) show some curvature indicative of a rate component second order in $\mathrm{MeOH}$, ie third order overall. The curvature is greatest in the experiments without added inert gas (Figure 1(a) $)^{33}$. In these experiments the total pressure is effectively that of $\mathrm{MeOH}$ and therefore any third body effect is changing from run to run. In the experiments at a total pressure of 5 Torr (Figure 1(b)) the bulk of the gas is comprised of $\mathrm{SF}_{6}$ and the curvature is not apparent. The experiments carried out with 2 Torr of added $\mathrm{SF}_{6}$ (Figure 1(c)) show only a slight curvature (just beyond the scatter of data points). Since in this set of experiments the pressure is varying less dramatically, this is some indication that $\mathrm{MeOH}$ might be exerting an effect other than that of a third body. Similar, but more clear-cut, effects were observed by us ${ }^{15}$ in the $\mathrm{SiH}_{2}+\mathrm{H}_{2} \mathrm{O}$ reaction. Although the effect found here is perhaps marginal, and the uncertainty high, it seemed nevertheless worthwhile to see whether the derived rate constant has a reasonable magnitude. The third order rate constant for the $\mathrm{SiH}_{2}+\mathrm{MeOH}$ reaction obtained here is compared with that for $\mathrm{SiH}_{2}+\mathrm{H}_{2} \mathrm{O}$ in Table 10. Also included are those for the third body stabilisation process for $\mathrm{SF}_{6}$ obtained from the RRKM modelling. Despite the uncertainties, the data show that the third order rate constants for $\mathrm{SiH}_{2}+\mathrm{MeOH}$ are both greater than those for $\mathrm{SiH}_{2}+\mathrm{H}_{2} \mathrm{O}$. This is to be expected since these numbers reflect the 
stabilisation rate constants for the energised adducts $\left(\mathrm{H}_{2} \mathrm{Si} \cdot \mathrm{O}(\mathrm{H}) \mathrm{R}^{*}\right)$ which depend, in turn, on their densities of states which clearly increase with molecular size ${ }^{27}$. What is more striking is that for $\mathrm{SF}_{6}$ as collision partner, the rate constant is an order of magnitude greater for the $\mathrm{MeOH}$ adduct compared with the $\mathrm{H}_{2} \mathrm{O}$ adduct, whereas for $\mathrm{MeOH}$ compared with $\mathrm{H}_{2} \mathrm{O}$ as collision partners, the rate constants increase by only ca a factor of two, although the uncertainty is particularly high. A different comparison of the numbers shows that the rate constant for stabilisation (or reaction) of the $\mathrm{H}_{2} \mathrm{Si} \cdot \cdot \mathrm{O}(\mathrm{H}) \mathrm{Me}$ zwitterion by $\mathrm{MeOH}$ relative to $\mathrm{SF}_{6}$ is $0.23( \pm 0.19)$. Given that $Z_{\mathrm{LJ}}(\mathrm{MeOH}) / Z_{\mathrm{LJ}}\left(\mathrm{SF}_{6}\right)$ is 1.24 (see Table 7) the stabilising efficiency of $\mathrm{MeOH}$ compared with $\mathrm{SF}_{6}$ is actually only $0.19( \pm 0.16)$. This is the opposite of the relative efficiencies for $\mathrm{SF}_{6}$ and $\mathrm{H}_{2} \mathrm{O}(2.6 \pm 0.2)$ in stabilising or reacting with $\mathrm{H}_{2} \mathrm{Si} \cdot \cdot \mathrm{OH}_{2}$. While we cannot dismiss a catalysed process for $\mathrm{MeOH}$, and its rate constant is comparable with (if not greater than) that for $\mathrm{H}_{2} \mathrm{O}$, the relativity with $\mathrm{SF}_{6}$ is much less striking. For the reaction of $\mathrm{SiH}_{2}$ with $\mathrm{H}_{2} \mathrm{O}$ the high efficiency of the second $\mathrm{H}_{2} \mathrm{O}$ molecule clearly pointed to a chemical effect. This was supported by the ab initio calculations which showed a low energy transition state corresponding to catalysed process (leading to $\mathrm{SiH}_{3} \mathrm{OH}$ formation). While the kinetics evidence for a similar effect in the $\mathrm{SiH}_{2}+\mathrm{MeOH}$ reaction is much weaker, nevertheless it is supported by the ab initio calculations (see below and Figure 11). It should be pointed out that the quadratic effects observed here could not have been seen under the higher pressure conditions used by $\mathrm{AKL}^{14}$.

Ab initio calculations and the mechanism. The calculations reported here are in reasonable accord with those of Heaven, Metha and Buntine $(\mathrm{HMB})^{13}$. Table 3 compares our G3 enthalpy values with the $\Delta E(\mathrm{MP} 2)$ of $\mathrm{HMB}^{13}$. Although these are not identical quantities they are normally close to one another. Our enthalpy values for the zwitterion and TS1 are also in agreement with those of an earlier study by Lee and Boo ${ }^{12}$ carried out at the MP4 level (not shown in the table). Compared with $\mathrm{HMB}^{13}$ our study has identified an extra pathway to 
the possible formation of $\mathrm{H}_{2}+\mathrm{HSiOMe}$, viz via $\mathrm{H}_{3} \mathrm{SiOMe}$ and TS3. Apart from this, the quantitative differences between the two studies are fairly small, the largest one being that of $18-20 \mathrm{~kJ} \mathrm{~mol}^{-1}$ between the values for TS2 (cis and trans) for formation of $\mathrm{H}_{2}+\mathrm{HSiOMe}$ directly from the zwitterion. Interestingly our values are negative (relative to $\mathrm{SiH}_{2}+\mathrm{MeOH}$ ) whereas those of $\mathrm{HMB}^{13}$ are positive. At first sight a negative value for either TS2c or TS2t might seem to suggest a facile reaction pathway for decay of the zwitterions but there is no indication of this from the experiments (see next section). However the structures of these transition states are tight corresponding to $A$ factors in the range $10^{12}-10^{13} \mathrm{~s}^{-1}$ (see supporting information) and so need to have more sizeable negative enthalpies for this pathway to be competitive with redissociation of the zwitterion to reactants (with its much looser transition state). The positive enthalpy for TS1, although not large in value, is sufficient, together with its also tight structure (and therefore low $A$ factor), to explain why conversion of the zwitterion to stable product, methoxysilane is also ruled out. These arguments were verified as part of the RRKM calculations and the results discussed in the next section.

The calculations for reaction of $\mathrm{SiH}_{2}$ with 2 molecules of $\mathrm{MeOH}$ show clearly that such a reaction is energetically feasible (both in terms of enthalpy and free energy). The transition state TS4a lies below the reaction threshold, showing that the $\mathrm{H}_{2} \mathrm{Si} \cdot \cdot(\mathrm{MeOH})_{2}$ complex can convert readily to the product $\mathrm{H}_{3} \mathrm{SiOMe}(\mathrm{MeOH})$, ie the methoxysilane with a weakly complexed $\mathrm{MeOH}$ molecule. This is parallel to the reaction of $\mathrm{SiH}_{2}$ with 2 molecules of $\mathrm{H}_{2} \mathrm{O}$, and a comparison of these two PE surfaces is shown in Figure 11. The diagram shows that the enthalpy surface for the $\mathrm{MeOH}$ case is more favourable than that of the $\mathrm{H}_{2} \mathrm{O}$ case, since both the complex and its rearrangement transition state are lower in enthalpy relative to their respective reactants (by 28 and $31 \mathrm{~kJ} \mathrm{~mol}^{-1}$ respectively). Figure 11 also shows the further comparison with the PE surfaces for the catalysed reactions of $\mathrm{SiH}_{2}+\mathrm{H}_{2} \mathrm{O}+\mathrm{MeOH}$, ie mixed catalysis (an exercise which is impossible to carry out experimentally). The data 
calculated here (Table 4) allow us to obtain the following specific catalytic enthalpy values. Replacement of $\mathrm{H}_{2} \mathrm{O}$ by $\mathrm{MeOH}$ in the zwitterionic position stabilises the complex by $21-22 \mathrm{~kJ}$ mol $^{-1}$, whereas replacement of $\mathrm{H}_{2} \mathrm{O}$ by $\mathrm{MeOH}$ in the second (ie the catalytic) position stabilises the complex by only 6-7 $\mathrm{kJ} \mathrm{mol}^{-1}$. Since in the uncatalysed process, $\mathrm{MeOH}-$ for- $\mathrm{H}_{2} \mathrm{O}$ substitution produces a zwitterionic stabilisation of $21 \mathrm{~kJ} \mathrm{~mol}^{-1}$, this tells us that in the two molecule case, the substitution effect is only a modest $6 \mathrm{~kJ} \mathrm{~mol}^{-1}$ above the thermodynamic stabilisation of the zwitterion. The effect is slightly different on the transition state. $\mathrm{MeOH}-$ for- $\mathrm{H}_{2} \mathrm{O}$ replacement in the zwitterionic position stabilises it by $17 \mathrm{~kJ} \mathrm{~mol}^{-1}$, whereas in the catalytic position the stabilisation is $14 \mathrm{~kJ} \mathrm{~mol}^{-1}$. The effects on the enthalpy barriers to the rearrangements of the two molecule complexes are more modest. The lowest barrier $(30 \mathrm{~kJ}$ $\mathrm{mol}^{-1}$ ) is for the $\mathrm{H}_{2} \mathrm{SiOH}_{2}$ zwitterion with $\mathrm{MeOH}$ catalysis and the highest $\left(42 \mathrm{~kJ} \mathrm{~mol}^{-1}\right)$ is for the $\mathrm{H}_{2} \mathrm{SiO}(\mathrm{H}) \mathrm{Me}$ zwitterion with $\mathrm{H}_{2} \mathrm{O}$ catalysis, but $\mathrm{MeOH}$ is clearly more effective as a catalyst. This undoubtedly arises because Me-for-H substitution facilitates the release of electron density which stabilises the transition state. Thus there is no doubt of the specific effect of $\mathrm{MeOH}$ relative to $\mathrm{H}_{2} \mathrm{O}$ in producing a more favourable reaction enthalpy surface. However the further comparisons of entropy and free energy present a slightly more complex picture. Not surprisingly the entropy values for formation of the complexes and transition states are all highly negative. Differences amongst the four systems are not large, but it is clear that the transition state structures are all tighter than their respective complexes. The consequences of this are that transition state free energy values (for formation from respective reactant species) are very small and, in three cases, positive. Positive values, if small, are not a disqualification for reaction, nor an indication of a particularly slow reaction. This is clear since the most positive value is that for the $\mathrm{SiH}_{2}+\mathrm{H}_{2} \mathrm{O}$ reaction, the only gas-phase case for which the experimental evidence exists hitherto ${ }^{15}$. The only negative value is that for the reaction of $\mathrm{SiH}_{2}+2 \mathrm{MeOH}$, studied here, which suggests it should, if anything, be more 
favourable. Since the experimental evidence for catalysis is marginal, the rate constant for it (Table 10) represents an upper limit, which could be, within the uncertainties, either larger or smaller than that for $\mathrm{SiH}_{2}+2 \mathrm{H}_{2} \mathrm{O}$. Thus we are forced to conclude that the balance of enthalpy and entropy effects combine to reduce any large difference between $\mathrm{MeOH}$ and $\mathrm{H}_{2} \mathrm{O}$ on this intriguing catalytic process, and that the ab initio calculations have enough uncertainty within them not to give a clearcut answer.

RRKM calculations, their implications and the reaction efficiencies. All five reactions studied have been found to be pressure dependent and all five have been modelled. Only the reaction between $\mathrm{SiH}_{2}$ and $\mathrm{MeOH}$ has been studied previously ${ }^{14}$ and the only comparison possible, shown in Figure 12, is for the pressure dependence in Ar. While the rate constants of $\mathrm{AKL}^{14}$ only overlap with ours at 100 Torr, the trends of the two data sets are closely similar and they also match reasonably well the RRKM calculated pressure dependence curve obtained here. $\mathrm{AKL}^{14}$ also carried out RRKM calculations, using a Gorin model transition state which corresponded to $\log \left(A / \mathrm{s}^{-1}\right)=17.25$. Their critical energy value $\left(82 \mathrm{~kJ} \mathrm{~mol}^{-1}\right)$ was also slightly different from ours $\left(74 \mathrm{~kJ} \mathrm{~mol}^{-1}\right.$, Table 4$)$, although AKL chose to base their value on equilibrium measurements rather than their own ab initio value of 74.5 $\mathrm{kJ} \mathrm{mol}^{-1}$. We can only say that our own calculations support a model with a tighter transition state (at ambient temperatures) corresponding to $\log \left(A / \mathrm{s}^{-1}\right)=16.0$ and that a model based on 17.25 would not fit the combined experimental data of Figure 12. The fits to pressure dependences for other bath gases (Figures 9 and 10) are all reasonably good which attests to the consistency of our model. The values found for $\langle\Delta E\rangle_{\text {down }}$ are reasonably consistent with those expected for the bath gases used ${ }^{32}$.

The lack of any obvious deviation to the pressure dependence curves at the lowest pressure (viz a levelling out) shows that no reactive exit channel for this reaction system can be competitive under the conditions. This enables us to put limits on the potential 
unimolecular rearrangement channels, viz $\mathrm{H}_{2}$ elimination from the $\mathrm{H}_{2} \mathrm{Si} \cdot \cdot \mathrm{O}(\mathrm{H}) \mathrm{Me}$ zwitterion to form $\mathrm{HSi}-\mathrm{OMe}$ and isomerisation to $\mathrm{H}_{3} \mathrm{SiOMe}$. The $\mathrm{SiH}_{2}+\mathrm{MeOH}+\mathrm{Ar}$ system, produces the slowest rate constant at $P=5.1$ Torr. The RRKM calculations give $k=0.6 \mathrm{~s}^{-1}$ for thermal redissociation of the zwitterions under these conditions. This provides the upper limit to the value for the rate constants for these rearrangement channels. In fact the limit should probably be an order of magnitude lower since the process is not visibly competitive. The value, nevertheless, shows that rearrangement is far too slow to be observed experimentally on the microsecond time frame of these experiments, even as a secondary process. The arguments against the occurrence of either of these processes are further supported by the results of the calculations of its rate constants based on the $E_{\mathrm{o}}$ values for TS1 and TS2t from the ab initio calculations. Table 9 shows that at the energies corresponding to the maximum populations of energized zwitterion species $\left(E_{\mathrm{o}}+\right.$ thermal energy) the rate of the redissociation process exceeds that of unimolecular rearrangement by factors in excess of 100 for $\mathrm{H}_{2}$ elimination and 1000 for isomerisation.

For the reactions of $\mathrm{SiH}_{2}$ with the other alcohols, the fits of the RRKM calculated pressure dependences to the experimental results (Figure 5) are reasonably good. The fits for 1-propanol and 1-butanol are very close but apparently cross; we suspect that this is an artefact arising from experimental error. Of course the models are matched to the curvature of these pressure dependences and so the fits have been optimised. The judgement of their success depends to a large extent on whether they produce reasonable values for the high pressure limiting rate constants, $k^{\infty}$. The values derived (at $297 \mathrm{~K}$ ), shown in Table 8, are all very close to the Lennard-Jones collision limits, corresponding to ca $60 \%$ of the value if the best fit models are used. Even with the less good fitting models the efficiencies are still quite high. Although for $\mathrm{SiH}_{2}+\mathrm{EtOH}$ the values of $k^{\infty}$ and the efficiency look slightly low, they are within the uncertainties of the values for the other systems. The rate constants increase with 
molecular mass and size of the alcohol, as expected, and the pressure dependences get less. The consequence of this is that, extrapolation to $k^{\infty}$ can be done with more confidence and less reliance on the RRKM model. Thus we can be reasonably confident in the values for these high efficiencies, particularly for the larger alcohols. It should be noted that the RRKM model used by $\mathrm{AKL}^{10}$ for $\mathrm{SiH}_{2}+\mathrm{MeOH}$ gives a value for $k^{\infty}$ of $1.43 \times 10^{-9} \mathrm{~cm}^{3}$ molecule $\mathrm{s}^{-1}$, a factor of ca 4.5 times greater than our extrapolated value corresponding to an efficiency of ca $290 \%$. Although $\mathrm{AKL}^{14}$ have explained this in terms of long range interactions, leading to an unusually high collision cross section, our results show that such an explanation is not necessary.

\section{Conclusions}

The findings of this work support the view that the reaction of silylene with an alcohol is a simple association process leading to a zwitterionic, donor-acceptor complex as the final product in the gas phase. The measured second-order rate constants for reactions of $\mathrm{SiH}_{2}$ with five alcohols are pressure dependent and, when extrapolated to infinite pressure by the use of RRKM theory, show that the reactions are occurring at close to the Lennard-Jones collision rate. The use of larger alcohols reduces significantly the extent of extrapolation necessary, and improves the reliability of this conclusion compared with that from the modelling of data for $\mathrm{SiH}_{2}+\mathrm{MeOH}$ alone. For the latter reaction, the finding of a kinetic component second order in $\mathrm{MeOH}$, suggests the existence of an additional catalysed reaction pathway. This is supported by ab initio calculations, which indicate a low energy process whereby the complex reacts with a second molecule of $\mathrm{MeOH}$ which converts it into methoxysilane $(+\mathrm{MeOH})$. The energetics of this process have been explored with other similar model processes, which define some specific $\mathrm{MeOH}-$ for- $\mathrm{H}_{2} \mathrm{O}$ substitution effects. This catalytic pathway, although at the limit of our detection capability, is nevertheless consistent with the solution findings of 
Leigh's group ${ }^{8}$ for the process of conversion of zwitterionic complexes into silyl ethers (siloxanes) in solution.

Acknowledgement. R.B. thanks the Ministerio de Educacion y Ciencia for support under Project CTQ2006-10512 and Royal Society of Chemistry for a journals grant.

Supporting Information Available: Details of vibrational assignments for the $\mathrm{SiH}_{2} \cdot \cdot \mathrm{ROH}$ complexes and their decomposition transition states and Lennard-Jones parameters for molecules of interest. This material is available free of charge via the Internet at http://pubs.acs.org.

\section{References and Notes}

(1) Gaspar, P. P.; West, R. Silylenes. In The Chemistry of Organic Silicon Compounds; Rappoport, Z., Apeloig, Y., Eds.; Wiley: Chichester, 1998; Vol. 2, Chapter 43, p 2463.

(2) Jasinski, J. M.; Becerra, R.; Walsh, R. Chem. Rev. 1995, 95, 1203.

(3) Becerra, R.; Walsh, R. Kinetics \& mechanisms of silylene reactions: A prototype for gasphase acid/base chemistry. In Research in Chemical Kinetics; Compton, R. G., Hancock, G., Eds.; Elsevier: Amsterdam, 1995; Vol. 3, p 263.

(4) Becerra, R.; Walsh, R. Phys. Chem. Chem. Phys. 2007, 9, 2817.

(5) Gillette, G. R.; Noren, G. H.; West, R. Organometallics 1989, 8, 487.

(6) Levin, G.; Das, P. K.; Bilgrien, C.; Lee, C. L. Organometallics 1989, 8, 1206.

(7) Moiseev, A. G.; Leigh, W. J. Organometallics 2007, 26, 6277.

(8) Leigh, W. J.; Kostina, S. S.; Bhattacharya, A.; Moiseev, A. G. Organometallics 2010, 29, 662.

(9) Tokitoh, N.; Ando, W. In Reactive Intermediate Chemistry, Moss, R. A., Platz, M. S., Jones, M. Jr., Eds.; Wiley \& Sons, NY, 2004, Chapter 14, p. 651 
(10) Raghavachari, K.; Chandrasekhar, J.; Gordon, M. S.; Dykema, K. J. J. Am. Chem. Soc. 1984, 106, 5853.

(11) Su, S.; Gordon, M. S. Chem. Phys. Lett. 1993, 204, 306.

(12) Lee, S. Y.; Boo, B. H. J. Mol. Struct. (THEOCHEM) 1996, 366, 79.

(13) Heaven, M. W.; Metha, G. F.; Buntine, M. A. J. Phys. Chem. A 2001, 105, 1185.

(14) Alexander, U. N.; King, K. D.; Lawrance, W. D. J. Phys. Chem. A 2002, 106, 973.

(15) Becerra, R.; Goldberg, N.; Cannady, J. P.; Almond, M. J.; Ogden, J. S.; Walsh, R. J. Am. Chem. Soc. 2004, 126, 6816.

(16) Baggott, J. E.; Blitz, M. A.; Frey, H. M.; Lightfoot, P. D.; Walsh, R. Int. J. Chem. Kinet. 1992, 24, 127.

(17) Alexander, U. N.; King, K. D.; Lawrance, W. D. Phys. Chem. Chem. Phys. 2001, 3, 3085.

(18) Becerra, R.; Cannady, J. P.; Walsh, R. J. Phys. Chem. A 2003, 107, 11049.

(19) Steele, K. P.; Weber, W. P. Inorg Chem. 1981, 20, 1302.

(20) Steele, K. P.; Tseng, D.; Weber, W. P. J. Organometal. Chem. 1982, 231, 291.

(21) Becerra, R.; Carpenter, I. W.; Gutsche, G. J.; King, K. D.; Lawrance W. D.; Staker, W. S.; Walsh, R. Chem. Phys. Lett. 2001, 333, 83.

(22) Jasinski, J. M.; Chu, J. O. J. Chem. Phys. 1988, 88, 1678.

(23) Damrauer, R.; Simon, R.; Laporterie, A.; Manuel, G.; Tae Park, Y.; Weber, W. P. J. Organomet. Chem. 1990, 391, 7.

(24) Frisch, M. J.; Trucks, G. W.; Schlegel, H. B.; Scuseria, G. E.; Robb, M. A.; Cheeseman, J. R.; Montgomery, Jr., J. A.; Vreven, T.; Kudin, K. N.; Burant, J. C.; Millam, J. M.; Iyengar, S. S.; Tomasi, J.; Barone, V.; Mennucci, B.; Cossi, M.; Scalmani, G.; Rega, N.; Petersson, G. A.; Nakatsuji, H.; Hada, M.; Ehara, M.; Toyota, K.; Fukuda, R.; Hasegawa, J.; Ishida, M.; Nakajima, T.; Honda, Y.; Kitao, O.; Nakai, H.; Klene, M.; Li, X.; Knox J. E.; Hratchian,H. P.; Cross,J. B.; Bakken, V.; Adamo, C.; Jaramillo, J.; Gomperts, R.; 
Stratmann, R. E.; Yazyev, O.; Austin, A. J.; Cammi, R.; Pomelli, C.; Ochterski, J. W.; Ayala, P. Y.; Morokuma, K.; Voth, G. A.; Salvador, P.; Dannemberg, J. J.; Zakrzewski, V. G.; Dapprich, S.; Daniels, A. D.; Strain, M. C.; Farkas, O.; Malick, D. K.; Rabuck, A. D.; Raghavachari, K.; Foresman, J. B.; Ortiz, J. V.; Cui, Q.; Baboul, A. G.; Clifford, S.; Cioslowski, J.; Stefanov, B. B.; Liu, G.; Liashenko, A.; Piskorz, P.; Komaromi, R.; Martin, R. L.; Fox, D. J.; Keith, T.; Al-Laham, M. A.; Peng, C. Y.; Nanayakkara, A.; Challacombe, M.; Gill, P. M. W.; Johnson, B.; Chen, W.; Wong, M. W.; Gonzales, C. and Pople, J. A., Gaussian 03, revision E.01, Gaussian, Inc., Wallingford CT, 2004

(25) Curtiss, L. A.; Raghavachari, K.; Redfern, P. C.; Rassolov, V.; Pople, J. A. J. Chem. Phys. 1998, 109, 7764.

(26) Gonzales, C.; Schlegel, H. B. J. Chem. Phys. 1989, 90, 2154.

(27) Holbrook, K.A.; Pilling, M.J.; Robertson, S.H. Unimolecular Reactions, $2^{\text {nd }}$ ed.; Wiley: Chichester, 1996.

(28) Becerra, R.; Cannady, J. P.; Goulder, O.; Walsh, R. J. Phys. Chem. A 2010, 114, 784

(29) Fredin, L.; Hange, R. H.; Kafafi, Z. H.; Margrave, J. L. J. Phys. Chem. 1985, 82, 3542.

(30) Shimamouchi, T. Molecular vibration frequencies. Tables of Molecular vibration frequencies, Consolidated Volume 1, NRDS-NB539, 1972.

(31) Benson, S. W. Thermochemical Kinetics, $2^{\text {nd }}$ ed.; Wiley: New York, 1976.

(32) Hippler, H.; Troe, J. in Advances in Gas Phase Photochemistry and Kinetics, Ashfold, M. N. R.; Baggott, J. E., Eds.; Royal Society of Chemistry: London, 1989, Vol. 2, Chapter 5, p. 209.

(33) A referee has queried whether this could be due to diffusion. We calculate that for $10 \%$ of $\mathrm{SiH}_{2}$ to be lost in this way from the observation zone at 1 Torr $\mathrm{MeOH}$, a diffusion rate constant of ca $10^{3} \mathrm{~s}^{-1}$ would be required, based on a estimated value of $83 \mathrm{~cm}^{2} \mathrm{~s}^{-1}$ for the 
diffusion constant (see supporting information). This value is an order of magnitude too low to account for the observed decay signals.

TABLE 1: Rate constants from second order plots (including quadratic fitting) for $\mathrm{SiH}_{2}+\mathrm{MeOH}$ at $297 \mathrm{~K}$

\begin{tabular}{lccc}
\hline Total Pressure $^{a}$ & $k_{\text {int }} / \mathrm{s}^{-1}$ & $k_{1}{ }^{b}$ & $k_{2}^{c}$ \\
\hline (a) variable & $4.1 \pm 1.1$ & $2.6 \pm 0.9$ & $2.9 \pm 1.2$ \\
(c) variable & $4.6 \pm 0.6$ & $4.5 \pm 0.6$ & $1.3 \pm 1.1$ \\
(b) 5 Torr & $4.66 \pm 0.45$ & $5.85 \pm 0.13$ & - \\
${ }^{a}$ see text for conditions & & ${ }^{b}$ Units: $10^{-12} \mathrm{~cm}^{3}$ molecule $^{-1} \mathrm{~s}^{-1}$ \\
${ }^{c}$ Units: $10^{-29} \mathrm{~cm}^{6}$ molecule &
\end{tabular}

TABLE 2: Experimental second-order rate constants for $\mathrm{SiH}_{2}+\mathrm{ROH}$ at 10 Torr total pressure and $297 \mathrm{~K}$

\begin{tabular}{|c|c|}
\hline $\mathrm{ROH}$ & $k / \mathrm{cm}^{3}$ molecule $\mathrm{s}^{-1}$ \\
\hline $\mathrm{MeOH}^{\mathrm{a}}$ & $(5.85 \pm 0.13) \times 10^{-12}$ \\
\hline $\mathrm{EtOH}$ & $(3.44 \pm 0.24) \times 10^{-11}$ \\
\hline 1-PrOH & $(8.52 \pm 0.37) \times 10^{-11}$ \\
\hline 1-BuOH & $(1.07 \pm 0.05) \times 10^{-10}$ \\
\hline $2-\mathrm{MBA}^{\mathrm{b}}$ & $(1.65 \pm 0.07) \times 10^{-10}$ \\
\hline at 5 Torr total pressure & ${ }^{b}$ 2-methyl-1-butano \\
\hline
\end{tabular}


TABLE 3: Ab initio G3 Enthalpies for Species of Interest in the $\mathrm{SiH}_{2}+$ MeOH Reaction

\begin{tabular}{lccc}
\hline Molecular Species & G3 Enthalpy & \\
& \multicolumn{1}{c}{$\mathrm{CSiH}_{6} \mathrm{O}$} & Relative $^{b}$ & $\mathrm{HMB}^{b, c}$ \\
\hline $\mathrm{SiH}_{2}+\mathrm{MeOH}$ & -406.078635 & 0 & \\
$\mathrm{H}_{2} \mathrm{Si} \cdots \mathrm{OHMe}$ & -406.107957 & -77 & -75.8 \\
$\mathrm{TS} 1$ & -406.077746 & +2 & +12.5 \\
$\mathrm{H}_{3} \mathrm{SiOMe}$ & -406.197471 & -312 & -304.1 \\
$\mathrm{TS} 2 \mathrm{c}$ & -406.079696 & -3 & +16.1 \\
$\mathrm{TS} 2 \mathrm{t}$ & -406.080087 & -4 & +14.9 \\
$\mathrm{H}_{2}+\mathrm{HSiOMe}(\mathrm{c})$ & -406.132165 & -138 & -128.1 \\
$\mathrm{H}_{2}+\mathrm{HSiOMe}(\mathrm{t})$ & -406.131030 & -140 & -125.5 \\
$\mathrm{TS} 3 \mathrm{c}$ & -406.098289 & -52 & - \\
$\mathrm{TS} 3 \mathrm{t}$ & -406.094839 & -43 & - \\
${ }^{a} H^{\mathrm{o}}(298 \mathrm{~K})$ values in Hartrees. & ${ }^{b}$ Relative energy in kJ mol ${ }^{-1}$ \\
${ }^{c} \mathrm{MP} 2 / 6-311++\mathrm{G}(\mathrm{d}, \mathrm{p})$ level, ref 13. &
\end{tabular}


TABLE 4: Ab initio G3 Thermodynamic Quantities at $298 \mathrm{~K}$ for Species of Interest in the $\mathrm{SiH}_{2}+2 \mathrm{MeOH}$ and related Reactions

\begin{tabular}{|c|c|c|c|}
\hline Molecular Species & $\Delta H^{a, b}$ & $\Delta S^{a, c}$ & $\Delta G^{a, b}$ \\
\hline $\mathrm{SiH}_{2}+2 \mathrm{MeOH}$ & 0 & 0 & 0 \\
\hline $\mathrm{H}_{2} \mathrm{Si} \cdots(\mathrm{OHMe})_{2}$ & -129 & -267 & -49 \\
\hline TS4a & -95 & -311 & -2 \\
\hline $\mathrm{H}_{3} \mathrm{SiO}(\mathrm{Me}) \cdots \mathrm{HOMe}$ & -331 & -254 & -255 \\
\hline $\mathrm{H}_{3} \mathrm{SiO}(\mathrm{Me})+\mathrm{MeOH}$ & -312 & -149 & -268 \\
\hline $\mathrm{SiH}_{2}+2 \mathrm{H}_{2} \mathrm{O}$ & 0 & 0 & 0 \\
\hline $\mathrm{H}_{2} \mathrm{Si} \cdots\left(\mathrm{OH}_{2}\right)_{2}$ & $-101\left(-103^{b}\right)$ & -248 & -27 \\
\hline $\mathrm{TS} 4 \mathrm{~b}$ & $-64\left(-59^{b}\right)$ & -291 & +23 \\
\hline $\mathrm{H}_{3} \mathrm{SiO}(\mathrm{H}) \cdots \mathrm{HOH}$ & $-317\left(-317^{b}\right)$ & -239 & -246 \\
\hline $\mathrm{H}_{3} \mathrm{SiOH}+\mathrm{H}_{2} \mathrm{O}$ & $-305\left(-305^{b}\right)$ & -139 & -264 \\
\hline $\mathrm{SiH}_{2}+\mathrm{H}_{2} \mathrm{O}+\mathrm{MeOH}$ & 0 & 0 & 0 \\
\hline $\mathrm{H}_{2} \mathrm{Si} \cdots \mathrm{OH}_{2} \cdots \mathrm{OHMe}$ & -108 & -254 & -32 \\
\hline TS4c & -78 & -298 & +11 \\
\hline $\mathrm{H}_{3} \mathrm{SiO}(\mathrm{H}) \cdots \mathrm{HOMe}$ & -320 & -237 & -249 \\
\hline $\mathrm{H}_{3} \mathrm{SiOH}+\mathrm{MeOH}$ & -305 & -139 & -264 \\
\hline $\mathrm{SiH}_{2}+\mathrm{MeOH}+\mathrm{H}_{2} \mathrm{O}$ & 0 & 0 & 0 \\
\hline $\mathrm{H}_{2} \mathrm{Si} \cdots \mathrm{OHMe} \cdots \mathrm{OH}_{2}$ & -123 & -262 & -45 \\
\hline TS4d & -81 & -301 & +9 \\
\hline $\mathrm{H}_{3} \mathrm{SiO}(\mathrm{Me}) \cdots \mathrm{HOH}$ & -326 & -247 & -252 \\
\hline $\mathrm{H}_{3} \mathrm{SiOMe}+\mathrm{H}_{2} \mathrm{O}$ & -312 & -149 & -268 \\
\hline \multicolumn{2}{|c|}{$\begin{array}{l}{ }^{a} \text { Values relative those of reactant species } \\
{ }^{d} \text { Ref. } 15\end{array}$} & ${ }^{b}$ Units: $\mathrm{kJ} \mathrm{mol}^{-1}$ & ${ }^{c}$ Units $\mathrm{J} \mathrm{K}^{-1} \mathrm{~mol}^{-}$ \\
\hline
\end{tabular}

TABLE 5: Ab initio G3 calculated energies of formation $\left(\mathrm{kJ} \mathrm{mol}^{-1}\right)$ of silylene complexes of ROH

\begin{tabular}{lccc}
\hline $\mathrm{ROH}$ & $\Delta E(0 \mathrm{~K})$ & $\Delta H(298 \mathrm{~K})^{a}$ & $\Delta G(298 \mathrm{~K})$ \\
\hline $\mathrm{MeOH}$ & -73.54 & $-77(-62)$ & -36.0 \\
$\mathrm{EtOH}$ & $-77.69^{b}$ & $-80(-64)$ & -39.6 \\
$1-\mathrm{PrOH}$ & -78.32 & $-81(-65)$ & -40.1 \\
$1-\mathrm{BuOH}$ & -78.96 & $-82(-65)$ & -40.6 \\
2-MBA & -76.50 & $-77^{c}$ & -
\end{tabular}

${ }^{a}$ Values in parenthesis at B3LYP level. $\quad{ }^{b} c f-78.6$ at MP2/6-311++G(d,p) level, ref 13.

${ }^{c}$ Approx value (see text) 
TABLE 6: Molecular and Transition State Parameters for RRKM

Calculations for Decomposition of the $\mathrm{H}_{2} \mathrm{Si} \cdots \mathrm{OHCH}_{3}$ Adduct

\begin{tabular}{|c|c|c|}
\hline Parameter & Molecule & $\mathrm{TS}(297 \mathrm{~K})$ \\
\hline C-H str(3) & $3000,2960,2844$ & $3000,2960,2844$ \\
\hline O-H str & 3663 & 3663 \\
\hline $\mathrm{Si}-\mathrm{H} \operatorname{str}(2)$ & 1965,1918 & 1965,1918 \\
\hline $\mathrm{C}-\mathrm{O}$ str & 1033 & 1033 \\
\hline $\mathrm{CH}_{3} \operatorname{def}(3)$ & 1477(2), 1455 & 1477(2), 1455 \\
\hline $\mathrm{CH}_{3} \operatorname{rock}(2)$ & 1165,1060 & 1165,1060 \\
\hline CÔH bend & 1355 & 1355 \\
\hline $\mathrm{SiH}_{2}$ bend & 977 & 977 \\
\hline $\mathrm{Si}-\mathrm{O}$ str & 776 & rxn coord \\
\hline SiÔC bend & 200 & 50 \\
\hline HÔSi bend & 500 & 60 \\
\hline $\mathrm{SiH}_{2}$ wag & 651 & 105 \\
\hline $\mathrm{SiH}_{2}$ rock & 257 & 90 \\
\hline $\mathrm{C}-\mathrm{O}$ torsion & 250 & 250 \\
\hline $\mathrm{Si} \cdots \mathrm{O}$ torsion & 150 & 70 \\
\hline$A / \mathrm{s}^{-1}$ & & $1.0 \times 10^{16}$ \\
\hline$E_{\mathrm{o}} / \mathrm{kJ} \mathrm{mol}^{-1}$ & & 73.54 \\
\hline$Z_{\mathrm{LJ}} / 10^{-10} \mathrm{~cm}^{3}$ molec $^{-1} \mathrm{~s}^{-1}$ & & 4.94 \\
\hline
\end{tabular}

TABLE 7: Lennard-Jones Collision numbers and energy removal parameters for collider gases

\begin{tabular}{lccccc}
\hline Parameter & $\mathrm{Ar}$ & $\mathrm{N}_{2}$ & $\mathrm{C}_{3} \mathrm{H}_{8}$ & $\mathrm{SF}_{6}$ & $\mathrm{MeOH}$ \\
\hline$Z_{\mathrm{LJ}} / 10^{-10} \mathrm{~cm}^{3} \mathrm{molec}^{-1} \mathrm{~s}^{-1}$ & 4.035 & 5.983 & 6.497 & 4.94 & 6.11 \\
$<\Delta \mathrm{E}>{ }_{\text {down }} / \mathrm{cm}^{-1}$ & 450 & 400 & 650 & 1000 & - \\
\hline
\end{tabular}


TABLE 8: Summary of high pressure limiting rate constants for reactions of $\mathrm{SiH}_{2}$ with alcohols from best fit RRKM calculations, together with collision efficiency estimates

\begin{tabular}{lccccc}
\hline Parameter & $\mathrm{MeOH}$ & $\mathrm{EtOH}$ & $1-\mathrm{PrOH}$ & $1-\mathrm{BuOH}$ & 2-MBA \\
\hline $\log \left(k^{\infty} / \mathrm{cm}^{3}\right.$ molecule $\left.^{-1} \mathrm{~s}^{-1}\right)$ & $-9.5^{a}(-10.1)^{b}$ & $-9.72^{a}$ & $-9.45^{c}(-9.62)^{a}$ & $-9.4^{d}(-9.80)^{a}$ & $-9.35^{d}(-9.63)^{a}$ \\
$k^{\infty} / 10^{-10} \mathrm{~cm}^{3}$ molecule $^{-1} \mathrm{~s}^{-1}$ & $3.16^{a}(0.79)^{b}$ & $2.00^{a}$ & $3.55^{c}(2.40)^{a}$ & $3.98^{d}(1.58)^{a}$ & $4.47^{d}(2.34)^{a}$ \\
$\mathrm{Z}_{\mathrm{LJ}} / 10^{-10} \mathrm{~cm}^{3}$ molecule $^{-1} \mathrm{~s}^{-1}$ & 5.12 & 5.305 & 5.973 & 5.946 & 6.525 \\
$\%$ Efficiency & $62(15)$ & 38 & $59(40)$ & $67(27)$ & $69(36)$ \\
${ }^{a} \log \left(\mathrm{A} / \mathrm{s}^{-1}\right)=16.0$ & ${ }^{b} \log \left(A / \mathrm{s}^{-1}\right)=15.0$ & ${ }^{c} \log \left(\mathrm{A} / \mathrm{s}^{-1}\right)=16.5$ & ${ }^{d} \log \left(A / \mathrm{s}^{-1}\right)=17.0$ &
\end{tabular}

TABLE 9: Comparison of energy specific rate constants, $k_{1}\left(E^{*}\right)$, for potential unimolecular rearrangement pathways of the $\mathrm{H}_{2} \mathrm{Si} \cdot \mathrm{OMe}$ zwitterions calculated via RRKM theory using the ab initio potential energy surface

\begin{tabular}{lccccc}
\hline$E^{*} / \mathrm{cm}^{-1 a}$ & $k_{\mathrm{diss}}\left(E^{*}\right) / \mathrm{s}^{-1 b}$ & $k_{1}\left(E^{*}\right) / \mathrm{s}^{-1 c}$ & $k_{1} / k_{\mathrm{diss}}$ & $k_{2 \mathrm{t}}\left(E^{*}\right) / \mathrm{s}^{-1 d}$ & $k_{2 \mathrm{t}} / k_{\mathrm{diss}}$ \\
\hline 6600 & $1.36 \times 10^{9}$ & 0 & - & $1.73 \times 10^{7}$ & $1.3 \times 10^{-2}$ \\
6800 & $4.60 \times 10^{9}$ & $2.25 \times 10^{6}$ & $4.9 \times 10^{-4}$ & $3.16 \times 10^{7}$ & $6.8 \times 10^{-3}$ \\
$7000^{e}$ & $1.16 \times 10^{10}$ & $7.04 \times 10^{6}$ & $6.1 \times 10^{-4}$ & $5.28 \times 10^{7}$ & $4.6 \times 10^{-3}$ \\
7200 & $2.40 \times 10^{10}$ & $1.24 \times 10^{7}$ & $5.2 \times 10^{-4}$ & $7.18 \times 10^{7}$ & $3.0 \times 10^{-3}$ \\
7400 & $4.36 \times 10^{10}$ & $1.74 \times 10^{7}$ & $4.0 \times 10^{-4}$ & $1.02 \times 10^{8}$ & $2.3 \times 10^{-3}$ \\
${ }^{a} 1 \mathrm{~cm}^{-1}=11.96 \mathrm{~J} \mathrm{~mol}^{-1}$ & ${ }^{b} k$ for dissociation & ${ }^{c} k$ via TS1 & ${ }^{d} k$ via TS2t & ${ }^{e}$ Energy \\
of maximum population of energized molecules & & &
\end{tabular}

TABLE 10: Third-order (limiting) rate constants for reactions of $\mathrm{SiH}_{2}$ with $\mathrm{H}_{2} \mathrm{O}$ and $\mathrm{MeOH}$ at $297 \mathrm{~K}$ for $\mathrm{ROH}\left(\mathrm{H}_{2} \mathrm{O}\right.$ or $\left.\mathrm{MeOH}\right)$ and $\mathrm{SF}_{6}$ as third bodies

\begin{tabular}{lcc}
\hline Reaction & \multicolumn{2}{c}{$k / 10^{-29} \mathrm{~cm}^{3}$ molecule $\mathrm{s}^{-1}$} \\
\hline & $+\mathrm{ROH}^{c, d}$ & $+\mathrm{SF}_{6}$ \\
\cline { 2 - 3 } $\mathrm{SiH}_{2}+\mathrm{H}_{2} \mathrm{O}^{a}$ & $0.60 \pm 0.04^{c}$ & 0.23 \\
$\mathrm{SiH}_{2}+\mathrm{MeOH}^{b}$ & $1.3 \pm 1.1^{d}$ & 5.60 \\
${ }^{a} \mathrm{Ref} \mathrm{15.} \quad{ }^{b}$ This work & ${ }^{c} \mathrm{ROH}=\mathrm{H}_{2} \mathrm{O} \quad{ }^{d} \mathrm{ROH}=\mathrm{MeOH}$ &
\end{tabular}




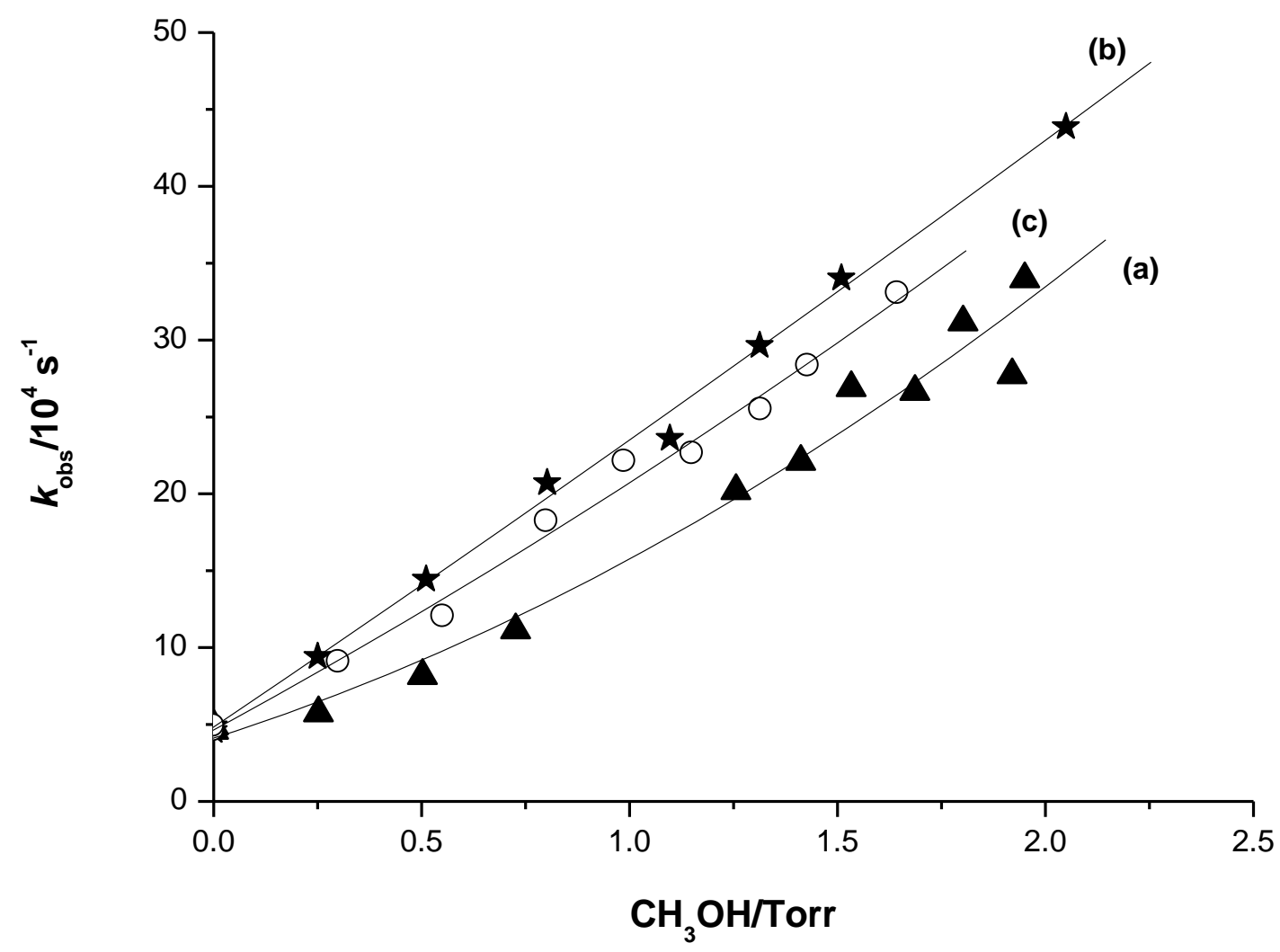

Figure 1. Second order rate plots for the reaction of $\mathrm{SiH}_{2}+\mathrm{MeOH}$ at $297 \mathrm{~K}$ under various conditions: $\boldsymbol{\Lambda}$, no buffer gas; $\star, 5$ Torr total pressure (made up with $\mathrm{SF}_{6}$ );, 2 Torr added $\mathrm{SF}_{6}$. Lines are LSQ best fits: (a) and (c) quadratic; (b) linear. 


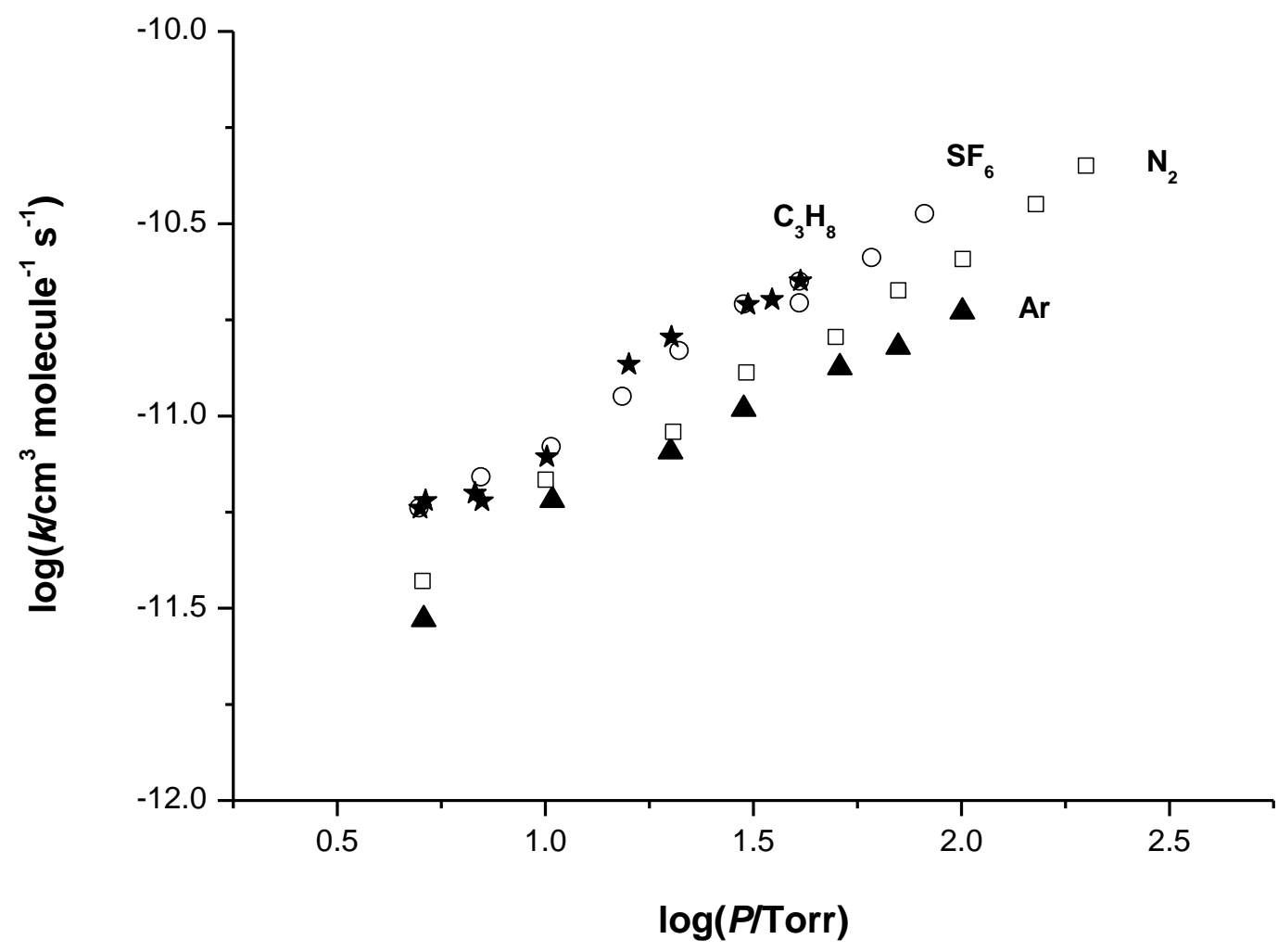

Figure 2. Pressure dependence of the second order rate constants for $\mathrm{SiH}_{2}+\mathrm{MeOH}$ at $297 \mathrm{~K}$ with different colliders, as indicated. 


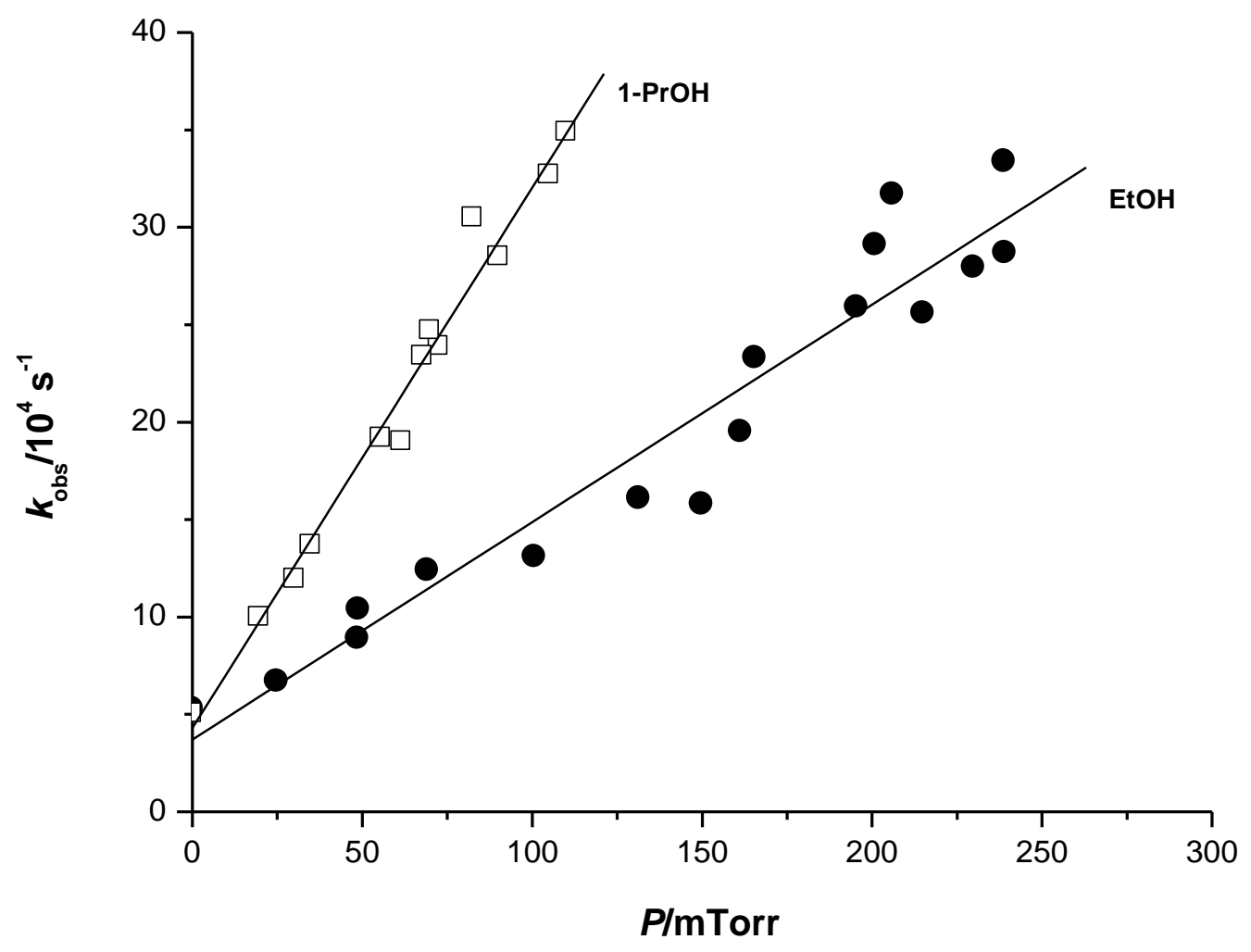

Figure 3. Second order plot for the reactions of $\mathrm{SiH}_{2}$ with $\mathrm{EtOH}$ and 1-PrOH at a total pressure of 10 Torr (added $\mathrm{SF}_{6}$ ) at $297 \mathrm{~K}$. 


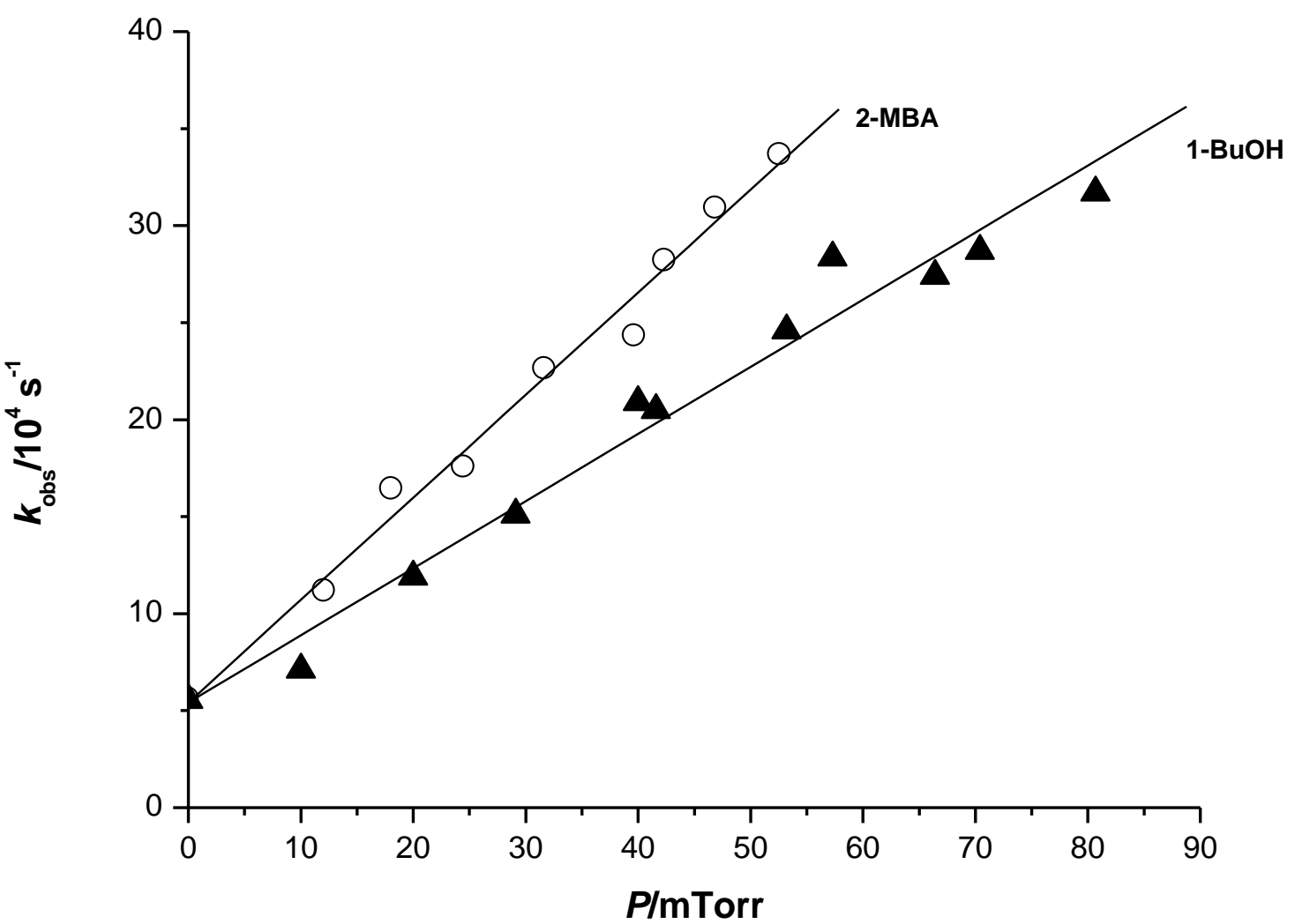

Figure 4. Second order plot for the reactions of $\mathrm{SiH}_{2}$ with 1-BuOH and 2-MBA at 10 Torr total pressure (added $\mathrm{SF}_{6}$ ) at $297 \mathrm{~K}$. 


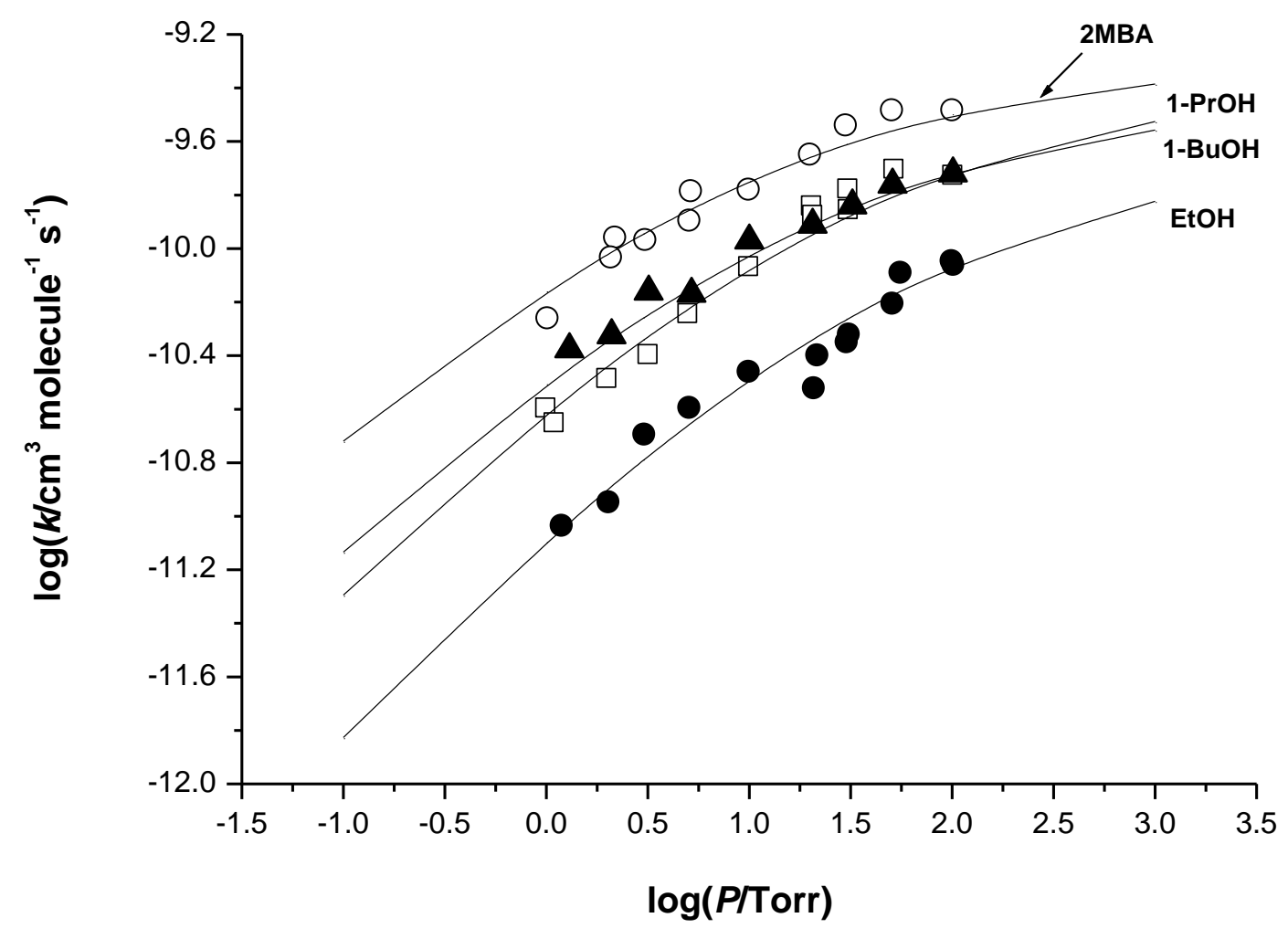

Figure 5. Pressure dependences for the second order rate constants for $\mathrm{SiH}_{2}+\mathrm{ROH}$ : •, $\mathrm{EtOH} ; \square, 1-\mathrm{PrOH} ; \boldsymbol{\Delta}, 1-\mathrm{BuOH} ; \circ, 2-\mathrm{MBA}$. Lines are RRKM theory best fits (see text). 


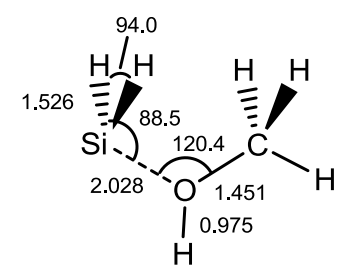

$\mathrm{H}_{2} \mathrm{Si} \cdots \mathrm{OHMe}$

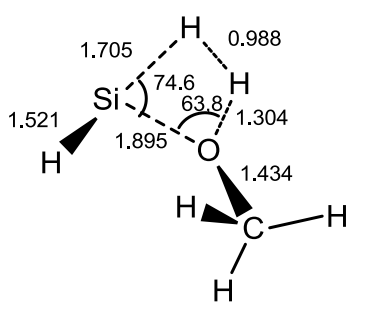

TS2c

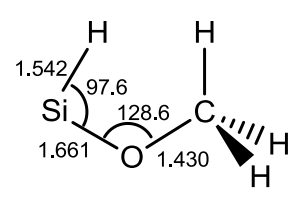

HSiOMe(c)

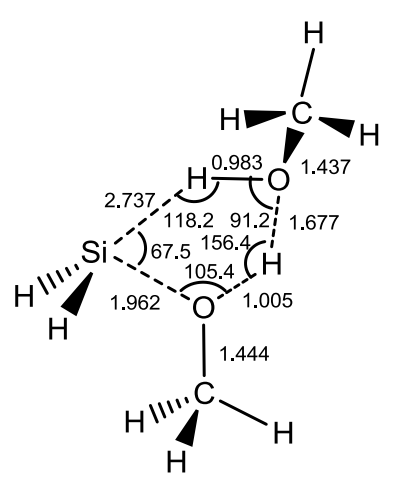

$\mathrm{H}_{2} \mathrm{Si} \cdot(\mathrm{OHMe})_{2}$

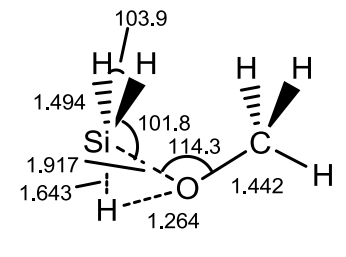

TS1

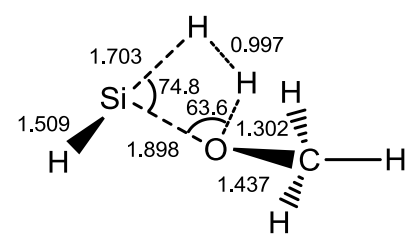

TS2t

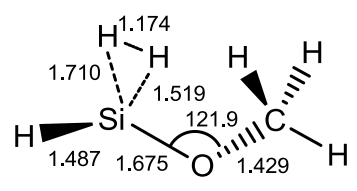

TS3t

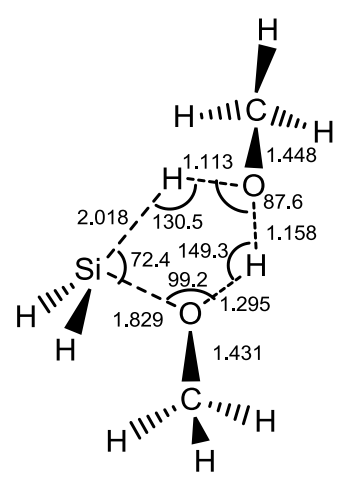

TS4a

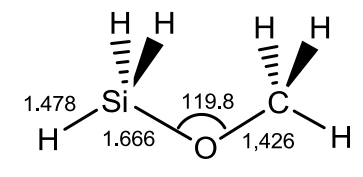

$\mathrm{H}_{3} \mathrm{SiOMe}$

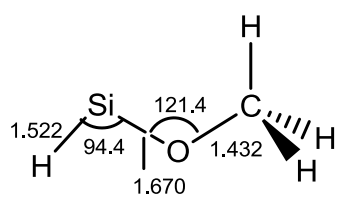

HSiOMe(t)

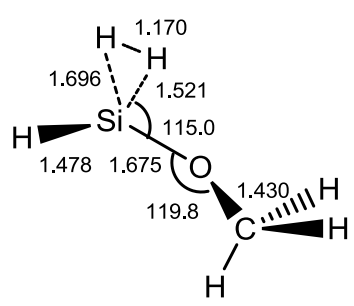

TS3c

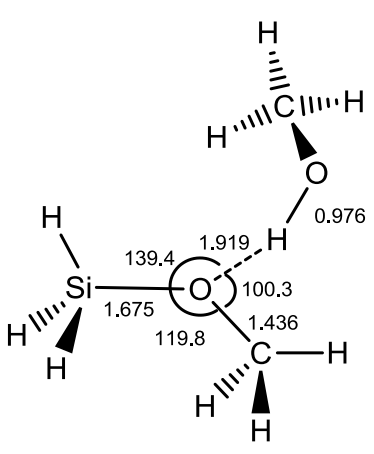

$\mathrm{H}_{3} \mathrm{SiO}(\mathrm{Me}) \cdots \mathrm{HOMe}$

Figure 6. Ab initio calculated (G3 level) geometries of local minima and transition states on the energy surfaces of the $\mathrm{SiH}_{2}+\mathrm{MeOH}$ and $\mathrm{SiH}_{2}+2 \mathrm{MeOH}$ reactions. Selected distances are given in $\AA$, and angles are in degrees. 


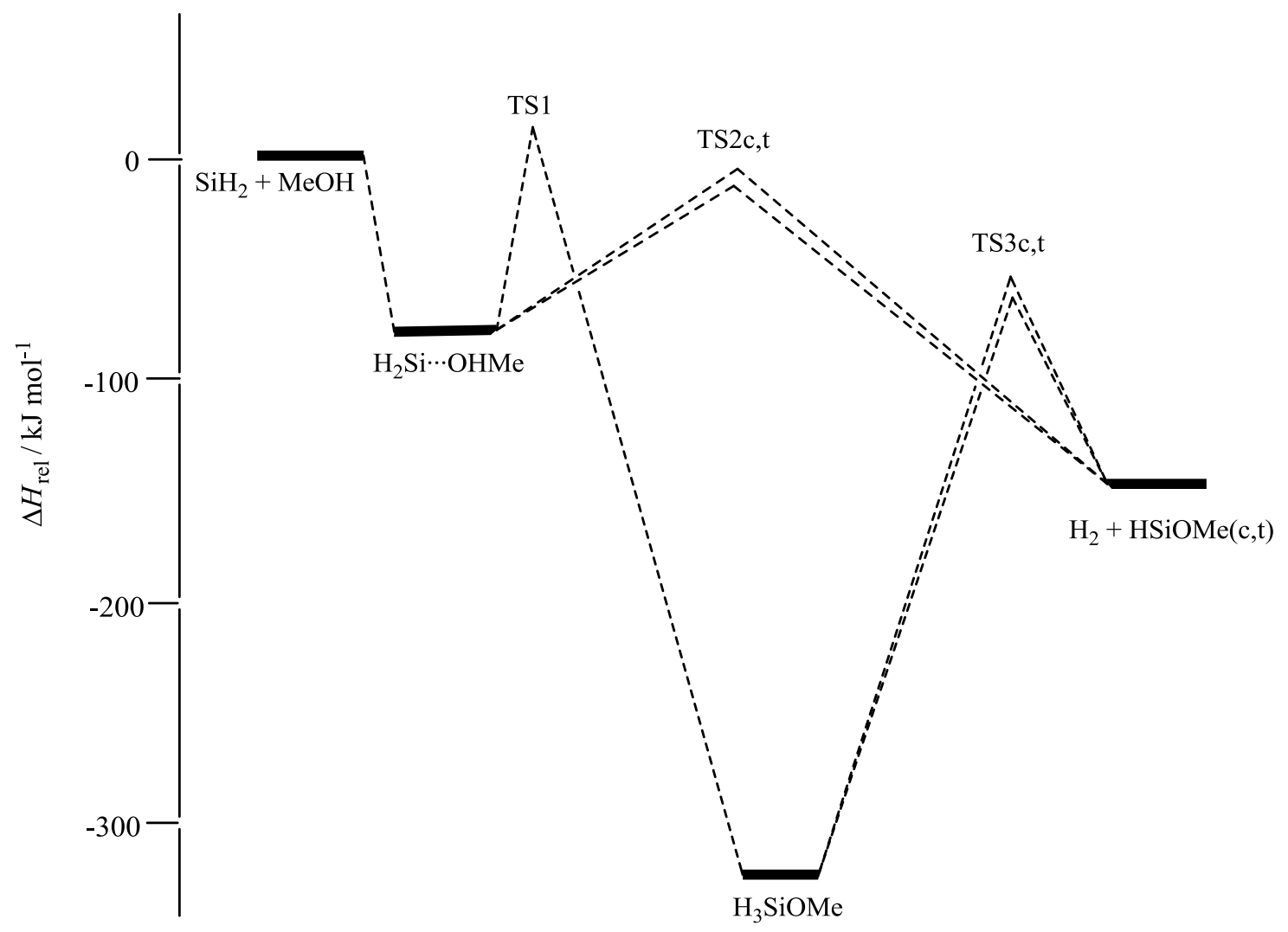

Figure 7. Potential energy (enthalpy) surface for the reaction of $\mathrm{SiH}_{2}+\mathrm{MeOH}$. All enthalpies are calculated at the G3 level. 


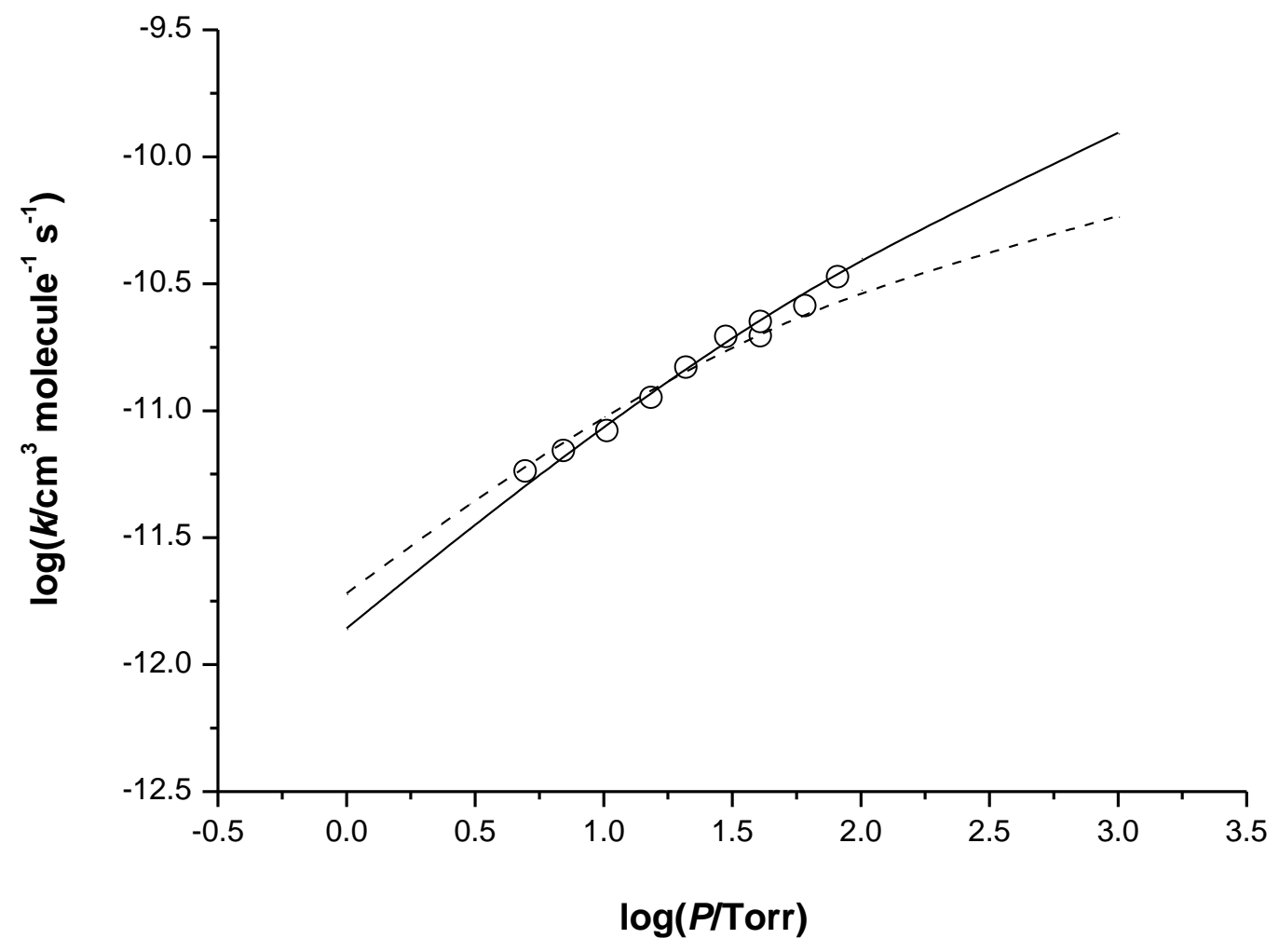

Figure 8. RRKM model fits to the pressure dependence for $\mathrm{SiH}_{2}+\mathrm{MeOH}$ (in $\mathrm{SF}_{6}$ ). Models: ,$\left.- \log \left(A / \mathrm{s}^{-1}\right)=16.0 ;----, \log \left(A / \mathrm{s}^{-1}\right)=15.0\right)$ 


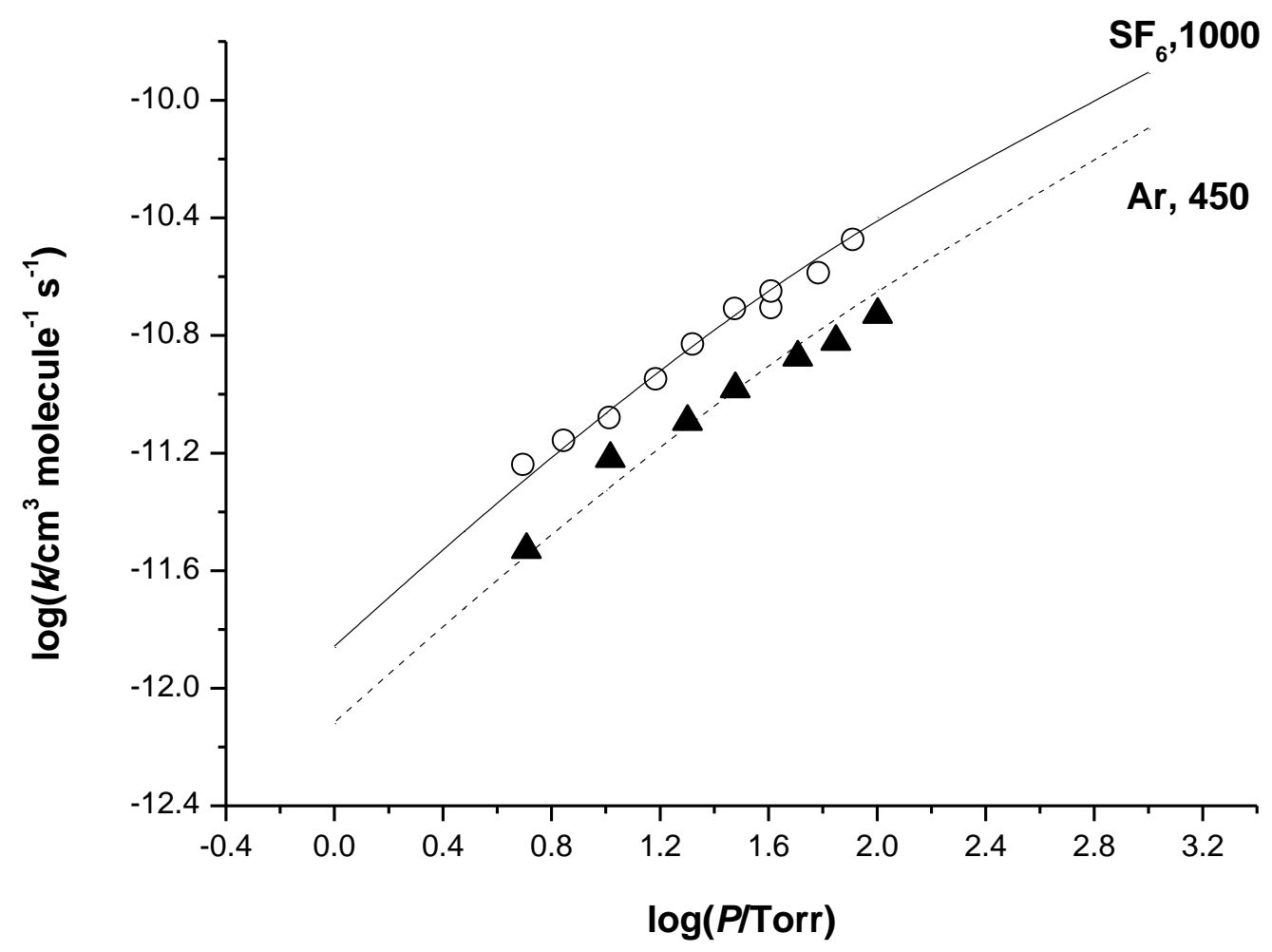

Figure 9. RRKM model $\left(\log \left(A / \mathrm{s}^{-1}\right)=16.0\right)$ fits to the pressure dependence for $\mathrm{SiH}_{2}+$ $\mathrm{MeOH}$. Data points: $\circ, \mathrm{SF}_{6} ; \boldsymbol{\Lambda}$, Ar. Lines and step sizes indicated. 


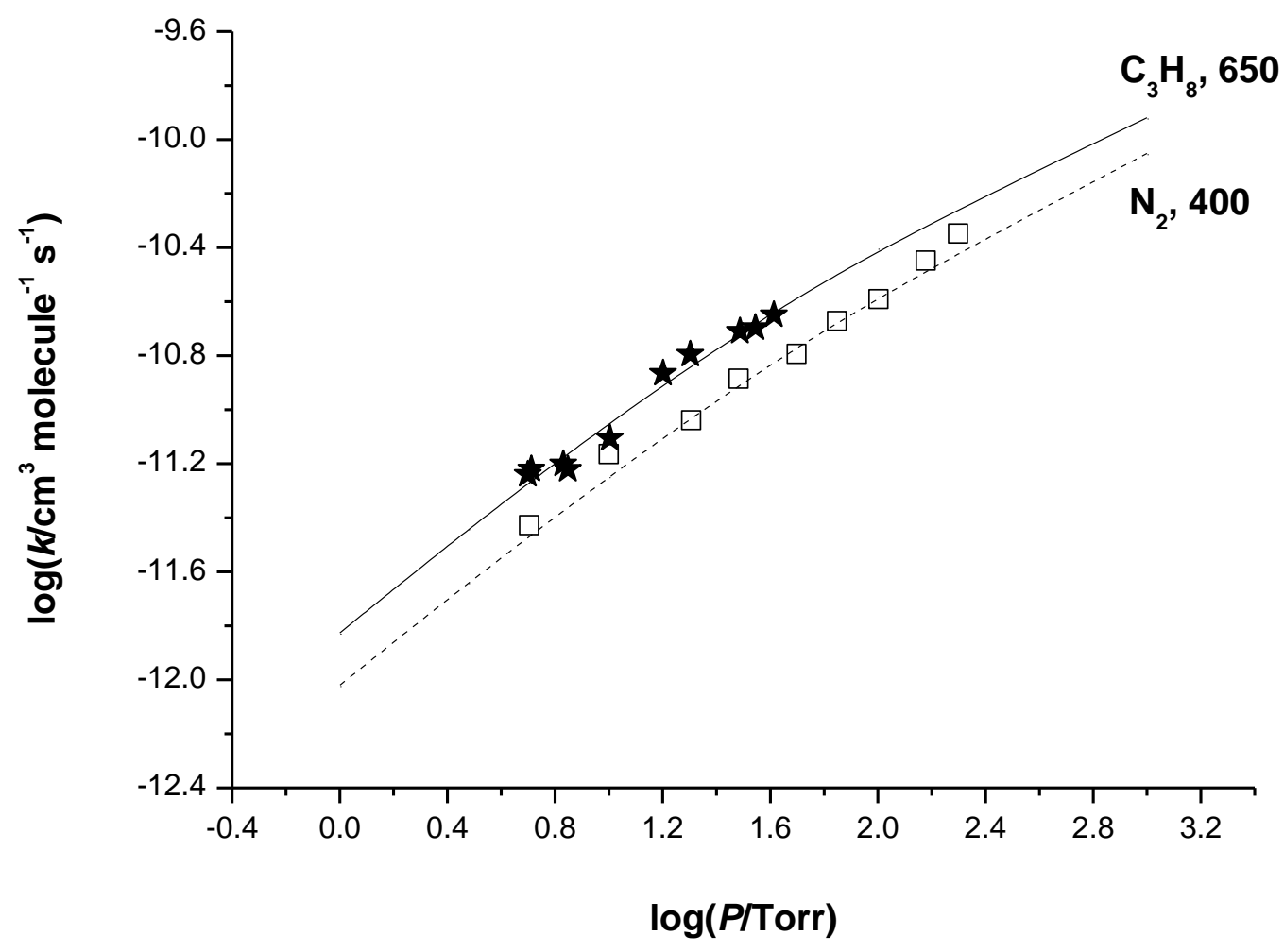

Figure 10. RRKM model $\left(\log \left(A / \mathrm{s}^{-1}\right)=16.0\right)$ fits to the pressure dependence for $\mathrm{SiH}_{2}+$ $\mathrm{MeOH}$. Data points: $\star, \mathrm{C}_{3} \mathrm{H}_{8} ; \square, \mathrm{N}_{2}$. Lines and step sizes indicated. 


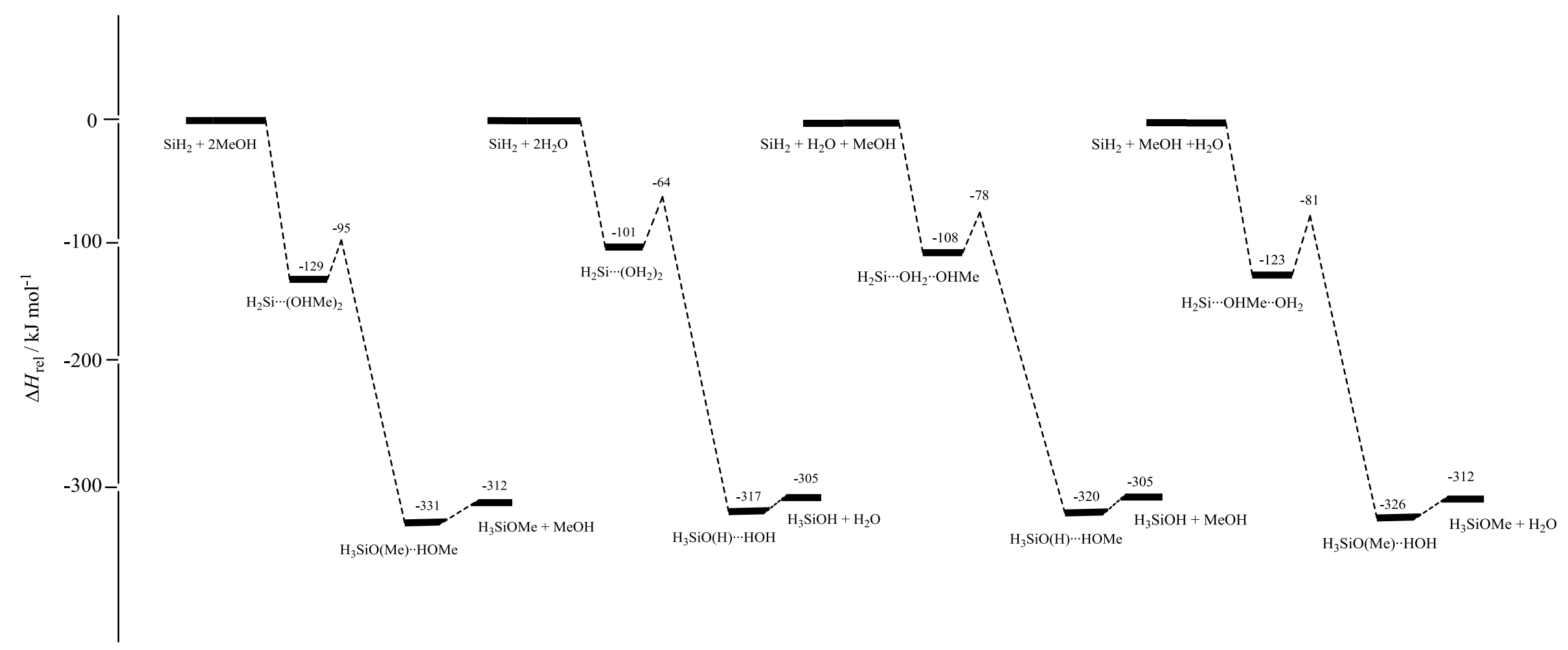

Figure 11. Comparison of $\mathrm{PE}$ surface (G3 level) for $\mathrm{SiH}_{2}+2 \mathrm{MeOH}$ with those for $\mathrm{SiH}_{2}+2 \mathrm{H}_{2} \mathrm{O}$ and $\mathrm{SiH}_{2}+\mathrm{MeOH}+\mathrm{H}_{2} \mathrm{O}$. 


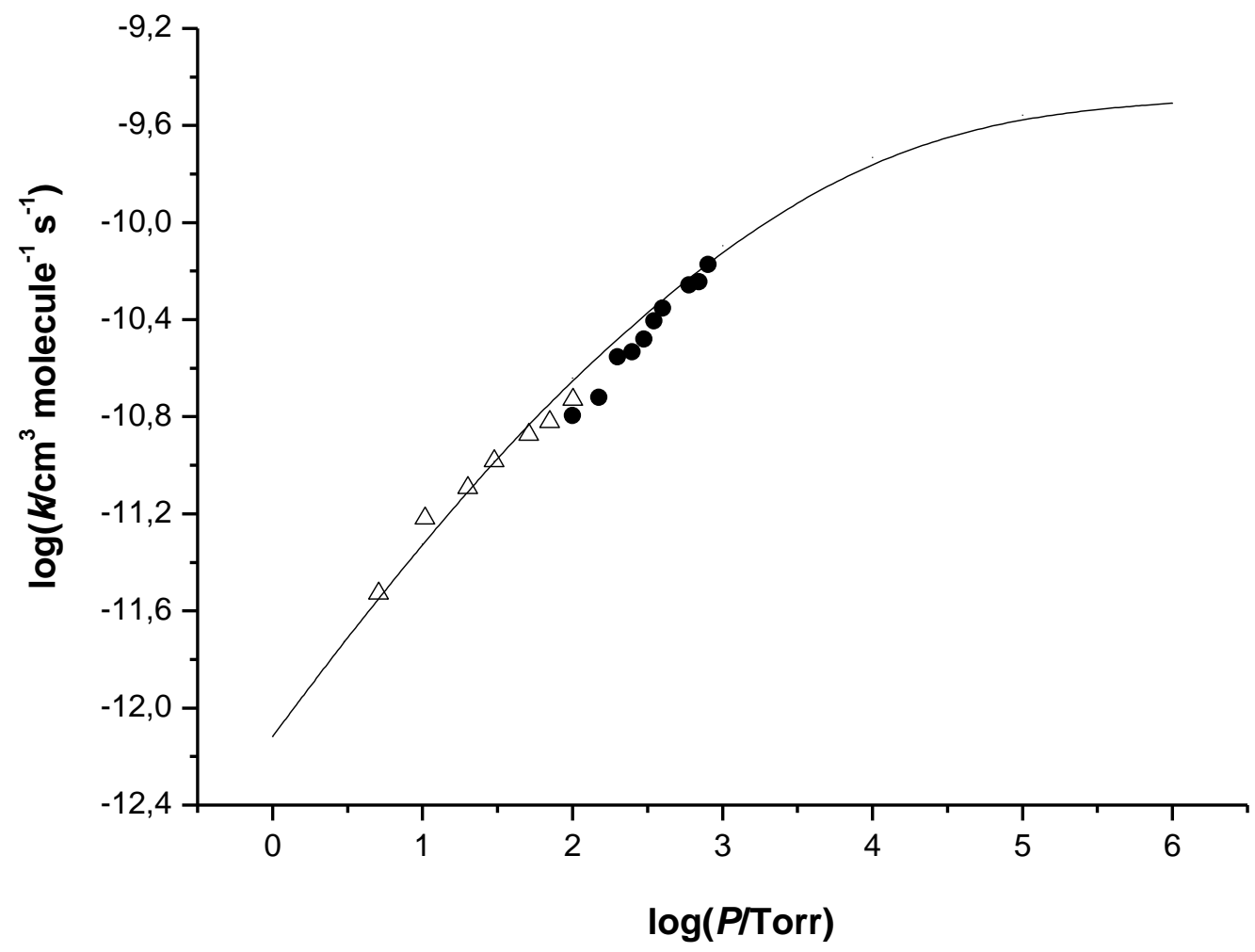

Figure 12. RRKM model $\left(\log \left(A / \mathrm{s}^{-1}\right)=16.0\right)$ fit to the pressure dependence for $\mathrm{SiH}_{2}+$ $\mathrm{MeOH}$ (in Ar). Experimental data: $\triangle$, this work; •, reference 14. 